Arıkan, A., Tomris, G., Yılmaz Bursa, G. ve Tuna, D. M. (2021). Özel gereksinimli bireylere yönelik farkındalık geliştirmede okul öncesi çocuk kitaplarımız nitelikli mi?. Ana Dili Eğitimi Dergisi, 9(1), 19-44.

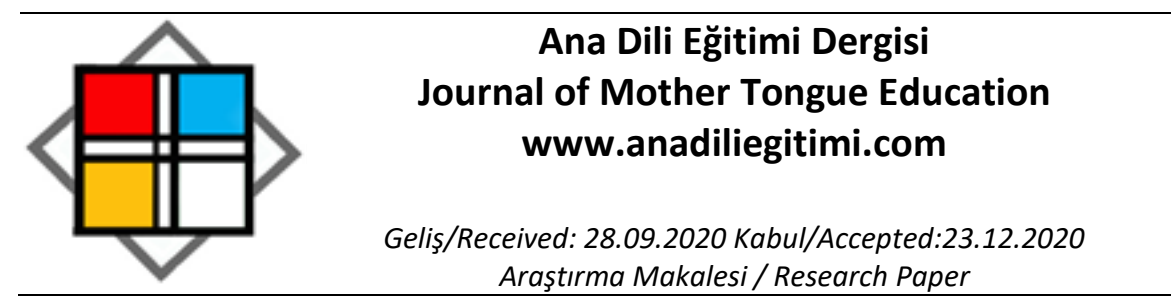

\title{
Özel Gereksinimli Bireylere Yönelik Farkındalık Geliştirmede Okul Öncesi Çocuk Kitaplarımız Nitelikli mi?*
}

\author{
Arzu ARIKAN** \\ Gözde TOMRIS ${ }^{* * *}$ \\ Gülhan YILMAZ BURSA ${ }^{* * * *}$ \\ D. Merve TUNA ${ }^{* * * * *}$
}

\begin{abstract}
Öz
$\mathrm{Bu}$ çalışmanın amacı özel gereksinimli karakterler içeren çocuk kitaplarının niteliklerini betimleyerek okul öncesi eğitimde özel gereksinimli bireylere yönelik farkındalık geliştirmek için başvurulabilecek kitapları belirlemektir. Bir doküman incelemesi olan bu nitel çalışmada özel gereksinimli karakterler içeren çocuk kitaplarının içerikleri değerlendirilmiştir. Örneklemin belirlenmesinde Türkiye'de kitap satışı yapan üç web sitesi ve çeşitli yayınevlerinin web siteleri taranmış ve ulaşılabilir örnekleme ile toplam 58 çocuk kitabına ulaşılmıştır. Bu kitaplardan seçim ölçütlerini karşılayan 20 tanesi belirlenmiştir. Kitaplar, araştırmacılar tarafından uluslararası bir araç kullanılarak değerlendirilmiş ve puanlayıcılar arası güvenirlik hesaplanmıştır. Bulgular, kitapların genel özellikleri, kişisel tasvirler, sosyal etkileşimler ve özel gereksinimli karakterlerin deneyimlediği örnek uygulamalar açısından olumlu veya kabul edilebilir nitelikte bulunan eserlerin özel gereksinimli bireylere yönelik farkındalık geliştirmede öğretmenler tarafından kullanılabileceğine işaret etmektedir. Ancak, bazı kitaplar için duyulan uyarlama gereksinimi, bazı yetersizliklerin kitaplardaki düşük temsili ve Türkçe yazılmış kitapların sayıca azlığı özel gereksinimli karakter içeren okul öncesi çocuk kitapları konusunda önemli bir boşluğa işaret etmektedir.
\end{abstract}

Anahtar Kelimeler: Kapsayıcı eğitim, Dolly Gray Çocuk Edebiyatı Ödülleri, kaynaştırma, bütünleştirme, doküman analizi, okul öncesi öğretmenleri

\section{How is the Quality of Preschool Children's Books in Raising Awareness About Individuals with Special Needs?}

\begin{abstract}
This study describes the qualities of preschool children's books containing special needs characters and identifies relevant books to raise awareness about special needs during preschool education. The qualitative study used document analysis and evaluated the books using an international scale. For sampling, three online bookstores and various publishers' websites were searched in Turkey. A total of 20 children's books met the selection criterion out of 58 children's
\end{abstract}

\footnotetext{
* Bu çalışmanın erken bir örneği 2019 yılında Kars'ta yapılan 6. Uluslararası Okul Öncesi Eğitimi Kongresi adlı bilimsel toplantıda sözlü bildiri olarak sunulmuştur.

** Dr. Öğr. Üyesi, Anadolu Üniversitesi, Eğitim Fakültesi, Temel Eğitim Bölümü, Eskişehir, arzuarikan@anadolu.edu.tr, ORCID: 0000-0002-4602-8901

*** Dr. Öğr. Üyesi, Eskişehir Osmangazi Üniversitesi, Eğitim Fakültesi, Özel Eğitim Bölümü, Eskişehir, gtomris@ogu.edu.tr, ORCID: 0000-0001-9035-9110

${ }^{* * * *}$ Arş. Gör., Anadolu Üniversitesi, Yunus Emre Sağlık Hizmetleri Meslek Yüksekokulu, Eskişehir, gulhanyilmaz@anadolu.edu.tr, ORCID: 0000-0003-2124-7013

${ }^{* * * * *}$ Uzm., Anadolu Üniversitesi, Eğitim Bilimleri Enstitüsü, Özel Eğitim Anabilim Dalı, Eskişehir, dmervetuna@gmail.com, ORCID: 0000-0002-4319-8286
} 
books. Inter-rater reliability was calculated to determine the reliability. The findings suggest that preschool teachers can use the books receiving positive or neutral quality ratings in different dimensions including general features of the books, personal portrayals, social interactions and exemplary practices to develop awareness about special needs. However, the observed need for adaptation for some books, underrepresentation of some disability groups, and an insufficient number of books written in the Turkish language reveal a critical gap regarding the children's books.

Keywords: Inclusive education, Dolly Gray Children's Literature Awards, mainstreaming, inclusion, document analysis, preschool teachers.

\section{Giriş}

Okul öncesi dönemden başlayarak özel gereksinimli bireylere yönelik farkındalık geliştirilmesi kapsayıcı eğitimin temel hedeflerinden biridir. Farklı sosyal, kültürel, ekonomik koşullarda ve gelişimsel özelliklerdeki bireylerin eğitim ortamlarına eşit erişimlerini vurgulayan kapsayıcı eğitim bu yönde pek çok hak temelli uygulamaları içermektedir. Çeşitli ülkelerin eğitim sistemlerinde hızla yer edinen bu uygulamalar, okullaşma reformları ve artan bilimsel çalışmalarla şekillenmektedir (Mncube ve Lebopa, 2019). Kapsayıcı uygulamaların en temel amacı, eğitim ortamlarında farklı özellikteki ve koşullara sahip bireylere yönelik önyargılar ve olumsuz tutumlardan kaynaklanan dışlanma ve ayrımcılığı ortadan kaldırmaktır (Eğitim Reformu Girişimi [ERG], 2016). Benzer şekilde, UNESCO (2017) da kapsayıcı eğitimde dışlanmış, ayrımcılık görmüş ve ötekileştirilmiş gruplara işaret ederek tüm öğrenciler için nitelikli eğitim fırsatlarını vurgulamaktadır. Eğitim Reformu Girişimi, kapsayıcı eğitimi cinsiyet, etnik köken, dil, din, yerleşim yeri, sağlık durumu, sosyoekonomik durum ve benzeri özelliklerinden ya da koşullarından bağımsız olarak tüm çocukların gereksinimlerini karşılayacak biçimde eğitim kurumlarının ve süreçlerinin yeniden düzenlenmesi şeklinde tanımlamaktadır (ERG, 2016). Nitelikli eğitim ve eşit koşulların vurgulandığı başka bir tanımda, kapsayıcı eğitim özellikle özel gereksinimli bireylerin yaşadıkları toplumun sosyal, kültürel, siyasal ve ekonomik yaşamına etkin katııım göstermelerini amaçlayan bir süreç olarak ele alınmaktadır (Stojik, 2009). Bu açıdan kapsayıcı eğitim, birlikte öğrenme ve sosyalleşmenin ötesinde, özel gereksinimli bireylerin toplumda seslerini duyurabilmelerini ve haklarını savunabilmelerini sağlayan önemli bir süreçtir ${ }^{1}$. Bilimsel araştırmalar da kapsayıcı eğitimin davranışsal, sosyal ve akademik gelişim açısından özel gereksinimli bireylere katkı sağladığını ve onları topluma kazandırdığını vurgulamaktadır (Ackah-Jnr, 2020; Armstrong, Armstrong ve Spandagou, 2010; Bricker, 1995; Odom, Buysse ve Soukakou, 2011; Rahayu ve Kurniawati, 2019; Siagian ve Kurniawati, 2019; Smith, Polloway, Patton ve Dowdy, 2012). Tipik gelişim gösterenler açısından da kapsayıcı eğitim okul öncesi çocuklarının özel gereksinimli bireyler konusunda bilgi edinmelerine, gelişimsel olarak desteklenmelerine, sınıftaki çalışmalara etkin katılmalarına, arkadaşlık ilişkilerine ve özel gereksinimli bireylere yönelik olumlu tutumlar geliştirmelerine katkı sunmaktadır (Bricker, 1995; Diamond ve Hestenes, 1996; Odom vd., 2006; Odom, Buysse ve Soukakou, 2011). Kapsayıcı eğitim uygulamalarının tipik gelişim gösteren çocukların empati kurabilme, başkalarının gereksinimlerinin farkına varma, farklılıklara karşı saygılı ve duyarlı olma, farklılıkları daha kolay kabul edebilme gibi alanlarda da önemli katkıları vardır (Diamond ve Hestenes, 1996; Peck, Carlson ve Helmstetter, 1992). Bu çerçevede, özel gereksinimli bireylerin genel eğitim ortamlarında akranları ile bir arada olmaları için pek çok ülkede çeşitli yasal düzenlemeler ve uygulamalar hayata geçirilmektedir.

Özel Gereksinimli Çocukların Hakları Bildirisi UNESCO (1994) ile Türkiye'de özel gereksinimli çocukların genel eğitim okullarında eğitim görmelerine ilişkin önemli değişiklikler yapılmaya başlanmıştır. Bu doğrultuda, 573 Sayılı Özel Eğitim Hakkında Kanun Hükmündeki Kararname (1997)

\footnotetext{
${ }^{1}$ Türkiye'deki gelişmelere paralel olarak özel gereksinimli çocukların akranları ile kaynaştırıldığı bir anlayıştan tüm çocukları kapsayan ve toplumla bütünleştiren bir eğitim anlayışına yönelim başlamıştır. Özellikle ulusal alan yazın değerlendirildiğinde kaynaştırma teriminin önce bütünleştirme terimi ile "kaynaştırma/bütünleştirme" şeklinde bir arada kullanıldığı (ERG, 2011); son yıllarda ise "kapsayıcı eğitim" kavramının tercih edildiği dikkat çekmektedir (ERG, 2016; MEB, 2018a). Bu çalışma kapsamında da güncel eğitim söylemine paralel olarak kapsayıcı eğitim kavramı tercih edilmiştir.
} 
ile özel gereksinimli bireylerin eğitimine ilişkin esaslar yeniden düzenlenmiştir. Nitekim bu kararnamenin 15. Maddesinde, "Özel gereksinimli olan bireylerin özel durumları ve farklılıkları dikkate alınarak yaşadıkları çevrede, bütünleştirilmiş ortamlarda, eşitlik temelinde, hayat boyu eğitim imkânından ayrımcılık yapılmaksızın yararlandırılır. Genel eğitim sistemi içinde özel gereksinimli bireylerin her seviyede eğitim almasını sağlayacak bütünleştirici planlamalara yer verilir" hükmünün olduğu görülmektedir. Bu düzenlemelerle Türkiye'de özel gereksinimli çocuklar için eğitimin temelleri atılmış, 2006 yılında da Birleşmiş Milletler Engelli Hakları Sözleşmesi imzalanarak yasa ve uygulamalardaki ayrımcılığı önlemek ve gidermek üzere önemli sorumluluklar üstlenilmiştir. Eğitim konusundaki son düzenlemeler incelendiğinde, Özel Eğitim Hizmetleri Yönetmeliğinin, otuz altıncı ayını dolduran ve genel eğitim sınıflarında akranları ile bir arada olabilecek durumdaki özel gereksinimli çocuklar için okul öncesi eğitimi zorunlu kıldığı görülmektedir (2018a, íkinci Kısım; Madde 11-b bendi). Genel nüfus içindeki yüksek oran dikkate alındığında eğitim konusundaki bu düzenleme özel gereksinimli çocuklar için önemli bir adımdır. Bu çerçevede, Milli Eğitim Bakanlığının eğitim verileri de 1260 özel gereksinimli çocuğun okul öncesi eğitim aldığını göstermektedir (2018b).

Türkiye'de özel gereksinimli çocukların eğitimi açısından geçmişten bugüne önemli gelişmeler kaydedilmekle birlikte bu konudaki çalışmalarda hala iyileştirmelere intiyaç duyulmaktadır. Nitekim alanyazın özel gereksinimli bireylerin, ailelerin ve öğretmenlerin eğitimde karşılaştıkları çeşitli sorunlara işaret etmektedir (Doğaroğlu ve Dümenci, 2015; Gök ve Erbaş, 2011; Kahriman-Pamuk ve Mazhar, 2019; Koçyiğit, 2015; Özaydın ve Çolak, 2011). Bu sorunlar, öğretmenlerin özel gereksinimli bireylerin eğitimlerine yönelik bilgi, kaynak ve destek yetersizliği yaşamaları, olumsuz tutumlara sahip olmaları ve okulların fiziksel yetersizlikleri şeklinde sıralanabilir. Tüm bunların yanında, özellikle okul öncesi çağındaki özel gereksinimli çocuklar, genel eğitim sınıflarında kabul görme, dâhil olma ve değerli olduğunu hissetme noktasında sorunlar yaşamaktadır. Bu açıdan, akran reddi özel gereksinimli çocukların karşılaştığı en önemli sorunlardan biridir (Bakkaloğlu, Sucuoğlu ve Özbek, 2019; Boer, Pijl, Post ve Minnaert, 2013; Eratay ve Sazak-Pınar, 2006; Karadağ, Yıldız-Demirtaş ve Girli, 2014; Metin, Şenol ve Yumuş, 2015; Odom vd, 2006; Wolfberg vd., 1999). Nitekim sosyal kabul konusunda yapılan sistematik bir derleme çalışmasında da özel gereksinimli çocukların kendilerini yalnız ve dışlanmış hissetme, ev dışındaki sosyal dünya ile sınırlı temasta bulunma, akran zorbalığı ve ayrımclık gibi olumsuz deneyimleri vurgulanmıştır (Woodgate vd, 2019). Metin, Şenol ve Yumuş (2015) okul öncesi eğitim kurumlarında otizm spektrum bozukluğu tanısı olan çocukların sosyal ve akademik alanlar ile farklı ortamlarda tercih edilme düzeylerinin çok düşük olduğunu ve akranları arasında genellikle dışlandığını belirtmişlerdir. Eratay ve Sazak-Pınar (2006) da zihinsel yetersizliği olan öğrencilerin sınıf ve okul ortamlarında yalnız kalan, dışlanan, oyun ve sıra arkadaşı olarak kabul edilmeyen, saldırgan ve olumsuz sosyal becerilere sahip öğrenciler olarak görüldüklerini bildirmiştir. Benzer şekilde Bakkaloğlu, Sucuoğlu ve Özbek (2019) tarafından yapılan çalışmada da özel gereksinimli çocukların akranlarına kıyasla sosyal kabul, öğrenci-öğretmen ilişkisi, sosyal beceri ve okula uyum puanlarının daha düşük olduğu bulunmuştur. Bu sorunlar erken yıllardan itibaren özel gereksinimli bireylere yönelik farkındalık geliştirilmesine duyulan intiyacı ortaya koymaktadır. Nitekim yapılan araştırmalar da tipik gelişim gösteren çocukların bakış açıları ve tutumlarını değiştirmenin ne kadar önemli olduğunu göstermektedir (Leininger, Dyches, Prater ve Heath, 2010; Ostrosky, Mouzourou, Dorsey, Favazza ve Leboeuf, 2015). Bu noktada nitelikli materyaller ve kaynaklara erişebilen öğretmenler değişimin başlatıcısı olabilirler.

Kapsayıcı eğitimin başarısında farklı paydaşların bilgi, tutum ve inançları, paydaşlar arası işbirliği ve destek, eğitim ortamı, öğretim programı, öğretmen eğitimi, fiziksel ve yasal altyapı gibi pek çok etmen bulunmaktadır (Bricker, 1995; miles, Wesley, Bryant ve Gardner, 1999; Siagian ve Kurniawati, 2019). Bu etmenler arasında özellikle sınıf öğretmenlerinin rolüne işaret edilerek kapsayıcı eğitim sürecinde sahip olmaları gereken bilgi, deneyim, tutum ve yeterlikler vurgulanmaktadır (Burke ve Sutherland, 2004; Siagian ve Kurniawati, 2019). Sınıf öğretmenlerinin temel sorumluluklarından biri özel gereksinimli bireylerin daha iyi anlaşılabilmesi için tipik gelişim gösteren çocuklara destek olmalarıdır. Bu sürecin yönetiminde ise öğretmene sunulan destek ve kaynaklar öne çıkmaktadır. Diğer bir ifadeyle, kapsayıcı eğitimi teşvik etmek ve öğretmenlerin çalışmalarını geliştirebilmek için erken çocukluk ortamlarında yeterli kaynakların bulunması önemlidir 
(Ackah-Jnr, 2020; Cross, Traub, Hutter-Pishgahi ve Shelton, 2004; Ostrosky vd., 2015). Zira okul öncesi öğretmenlerinin özel gereksinimli bireylere yönelik farkındalık geliştirme konusunda yaptıkları çalışmalar farklı etkinlikler ve materyallerin kullanımını içermektedir. Uluslararası alan yazında bu çalışmaların bilgilendirme ve açıklama toplantıları, tanışma ve kaynaştırma etkinlikleri, tartışma, drama çalışmaları, video gösterimleri, animasyonlar, kukla gösterileri, bültenler, okul gazeteleri, posterler ve çocuk kitaplarının kullanımı gibi örneklerine rastlanmaktadır (Dyches, Prater ve Cramer, 2001; Ostrosky vd., 2015). Bu noktada, çocuk edebiyatı ve kitaplara özel gereksinimli bireylere yönelik farkındalık geliştirme kapsamında sıklıkla başvurulmaktadır (Dyches, Prater ve Cramer, 2001; Leininger, Dyches, Prater ve Heath, 2010; Smith-D'Arezzo ve Thomas, 2010).

Çocuk kitaplarının özel gereksinimli bireylere yönelik olumlu tutumlar geliştirmedeki önemi çeşitli çalışmalar tarafından vurgulanmaktadır (Dyches ve Prater, 2005; Prater, Dyches ve Johnstun, 2006; Ostrosky vd., 2015; Smith-D’Arezzo ve Thomas, 2010). Örneğin, kitap okuma ve tartışma gibi etkinliklerle sınıftaki tüm çocuklara özel gereksinimlilik konusunda güncel ve yeni kelimeler kazandırılabileceğine işaret edilmiştir (Ostrosky vd., 2015). Bu çalışmalar, okul öncesinde çocuk kitaplarının sadece dil gelişimi alanında değil bilişsel ve sosyal-duygusal alanlarda da kritik becerilerin desteklenmesinde önemli olduklarını göstermektedir. Nitekim Favazza, Ostrosky ve Mouzourou (2016) erken çocuklukta farklııkların kabulü ve olumlu tutumların desteklenmesine yönelik geliştirdikleri müdahale programlarında çocuk kitaplarına başvurmuşlardır. Işıtan (2016) da özel amaçla yazılmış çocuk kitaplarında sınırlı da olsa özel gereksinimli bireylere yer verildiğine dikkat çekmiştir. Okul öncesi eğitimde çocukların öğrenmesi için oyun kadar önemli olan çocuk kitaplarına farkındalık geliştirmede de başvurularak tipik gelişen çocukların özel gereksinimli bireylere yönelik olumlu tutumlar kazanmaları desteklenebilir. Bunun içinse okul öncesi öğretmenlerinin de farkındalıklarının yüksek olması ve farklı kitaplar arasından amaçlarına uygun olanları seçebilmeleri gerekmektedir. Bu açıdan özel gereksinimli karakterler içeren çocuk kitaplarının bazı nitelikleri öne çıkmaktadır. Çocuk kitaplarında özel gereksinimli karakterlerin olumlu ve gerçekçi temsilleri, kapsayıcı eğitim bağlamında önemli görülen nitelikler olup uluslararası alanyazında bu türden kitapların örnek listelerine ve ayrıntılı betimlemelerine rastlanmaktadır (Dyches, Prater ve Leininger, 2009; Dyches, Prater ve Cramer, 2001; Prater, Dyches ve Johnstun, 2006; Price, Ostrosky ve Mouzourou, 2016). Bu çalışmalara benzer şekilde Türkiye'de de özel gereksinimli karakterler içeren çocuk kitaplarının belirlenerek okul öncesi öğretmenlerine intiyaç duydukları nitelikli kaynaklar sunulabilir. Bu kaynakları eğitimde farkındalık geliştirmek ve olumlu tutumları desteklemek amacıyla kullanabilen öğretmenlerin de mesleki açıdan kendilerini daha yetkin hissedecekleri ve özel gereksinimli bireylerin olduğu sınıflarda örnek uygulamaları ile çocukların yaşamlarında fark yaratabilecekleri söylenebilir.

Bu çalışmada özel gereksinimli karakterler içeren okul öncesi çocuk kitaplarının nitelikleri betimlenerek Türkiye'de okul öncesi öğretmenlerinin kullanabilecekleri kaynakları belirlemek hedeflenmiştir. Illgili alanyazın incelendiğinde özel gereksinimli karakterler içeren çocuk kitaplarının çeşitli uluslararası çalışmalarda değerlendirildiği (Dyches, Prater ve Cramer, 2001; Dyches, Prater ve Leininger, 2009; Dyches vd., 2018) ulusal alanyazında ise bu alana ilginin son yıllarda artmaya başladığı söylenebilir (Gönen, Dursun, Topçu-Bilir, Tarman ve Nur, 2015; Kaymaz, 2017; Kırkgöz ve Diken, 2019; Yakar, Yılmaz ve Yılmaz, 2019). Türkiye'deki araştırmalarda çocuk kitaplarının araştırmacılar tarafından geliştirilen formlar aracılığı ile değerlendirildiği ve farklı yaş gruplarını hedefleyen kitapların incelendiği dikkat çekmektedir (Kaymaz, 2017; Kırkgöz ve Diken, 2019). Çocuk kitaplarını temel alan diğer araştırmalar ise kitapların iç ya da dış yapı özellikleri ve odaklandıkları konular açısından durum tespiti yapan betimleyici çalışmalardır (Dirican ve Dağlıoğlu, 2014; Güzelyurt ve Saraç, 2018; Işıtan, 2016; Sevim, 2020; Şahin, 2014; Yıldız, Yazıcı ve Durmuşoğlu, 2016). Bu araştırmalardan, Türkiye'de çocuk kitaplarını içeren çalışmaların 2000li yıllardan itibaren başladığı ve okul öncesi yaş grubunda özel gereksinimli bireylerle ilgili sınırlı sayıda araştırma olduğu görülmektedir. Bu açıdan, yeni araştırmaların hem okul öncesi hem de özel eğitim alanlarına özgün katkılar sağlayacağı düşünülmektedir. Nitekim bu çalışma da okul öncesi odağı ile özel gereksinimli bireyler konusunda çocuk kitaplarının kapsayıcı bir değerlendirmesini içerdiğinden ulusal alanyazına önemli bir katkı sağlayacaktır. Araştırmada ödüllü kitapların belirlenmesinde kullanılan uluslararası bir değerlendirme aracına başvurulması da bu çalışmayı diğerlerinden ayırmakta ve alana özgün bir katkı 
sağlamaktadır. Son olarak, okul öncesi öğretmenlerinin kapsayıcı uygulamalarını destekleyecek somut kaynaklar sunması bakımından da bu çalışma diğer çalışmalardan ayrılmaktadır. Bu arka plan ışığında, çalışmanın amacı özel gereksinimli karakterler içeren çocuk kitaplarının niteliklerini betimleyerek okul öncesi eğitim sürecinde özel gereksinimli bireylere yönelik farkındalık geliştirmede başvurulabilecek kitapları belirlemektir. Bu temel amaç doğrultusunda aşağıdaki sorulara yanıt aranmıştır:

- Özel gereksinimli karakterler içeren çocuk kitaplarının genel özellikleri nasıldır?

- Çocuk kitaplarında özel gereksinimli karakterlerin kişisel özellikleri nasıl tasvir edilmiştir?

- Çocuk kitaplarında özel gereksinimli karakterlerin sosyal etkileşimleri nasıl betimlenmiştir?

- Çocuk kitaplarında özel gereksinimli karakterlerin deneyimlediği örnek uygulamalar nelerdir?

\section{Araştırmanın Modeli}

\section{Yöntem}

Bu nitel araştırmada doküman incelemeye başvurularak özel gereksinimli karakterler içeren okul öncesi dönem çocuk kitaplarının içerikleri analiz edilmiştir. Nitel araştırma betimleyici ve keşfedici doğası gereği daha az veri kullanarak derinlemesine analizi mümkün kılan bir yöntemdir. Doküman incelemesinde de fotoğraf, resim, film veya metin içeren kaynaklara başvurulması ve incelenen kaynakların araştıılan olay ya da olgular ile ilgili bilgi bulundurması esastır. Bu çalışmanın betimleyici amacına yönelik olarak temel veri kaynağı olarak kitaplar kullanılmıştır. Doküman analizi olarak da isimlendirilen doküman incelemesine, çeşitli nitel araştırmalarda veri toplama tekniği veya araştırma yöntemi olarak da başvurulduğu gibi dokümanlar çeşitleme amacıyla veya tek başına veri kaynağı olarak da kullanılabilmektedir (Karasar, 2013; Yıldııım ve Şimşek, 2011; Ulutaş, 2015).

\section{Veri Kaynağı}

Bu çalışmada veri kaynağı olarak çocuk kitapları kullanılmıştır. Çocuk kitaplarına erişmek için amaçlı örnekleme yöntemlerinden kolay ulaşılabilir örnekleme ve ölçüt örneklemeye başvurulmuştur. Kolay ulaşılabilir örneklemede araştırmacı açısından erişimi kolay ve ulaşılabilir veri kaynaklarına başvurulurken ölçüt örneklemede araştırmacının önceden belirlediği bir dizi ölçütün kullanımı söz konusudur (Yıldırım ve Şimşek, 2011). Bu araştırmada da öğretmenlerin kolay ulaşabileceği kaynakları derlemek amacıyla ulaşılabilir örnekleme, hedef kitle göz önüne alındığında okul öncesi dönem çocuklarının gelişimine uygun kitapları belirlemek amacıyla da ölçüt örnekleme tercih edilmiştir. Kolay ulaşılabilir örnekleme ile erişilen 58 çocuk kitap arasından temel ölçütleri taşıyan 20 kitap değerlendirmeye alınmıştır. Örnekleme süreci iki aşamada gerçekleştirilmiştir. Illk aşamada, 2019 yılı Mayıs-Temmuz aylarını kapsayan süre boyunca internet üzerinden tarama gerçekleştirilmiştir. Özel gereksinimli karakterlerin olduğu çocuk kitaplarının sayısı yetersiz olduğundan belirli bir yıl aralığı ile sınırlama yapılmamıştır. Tarama sürecinde Türkiye'de çevrimiçi kitap satışı yapan Kitapyurdu, Idefix ve $D \& R$ isimli web sitelerinden ve çocuk kitapları yayınlayan 49 yayınevinin web sitelerinden faydalanıımıştır. Örnekleme sürecinde izlenen aşamalar Şekil 1.'de gösterilmiştir. 


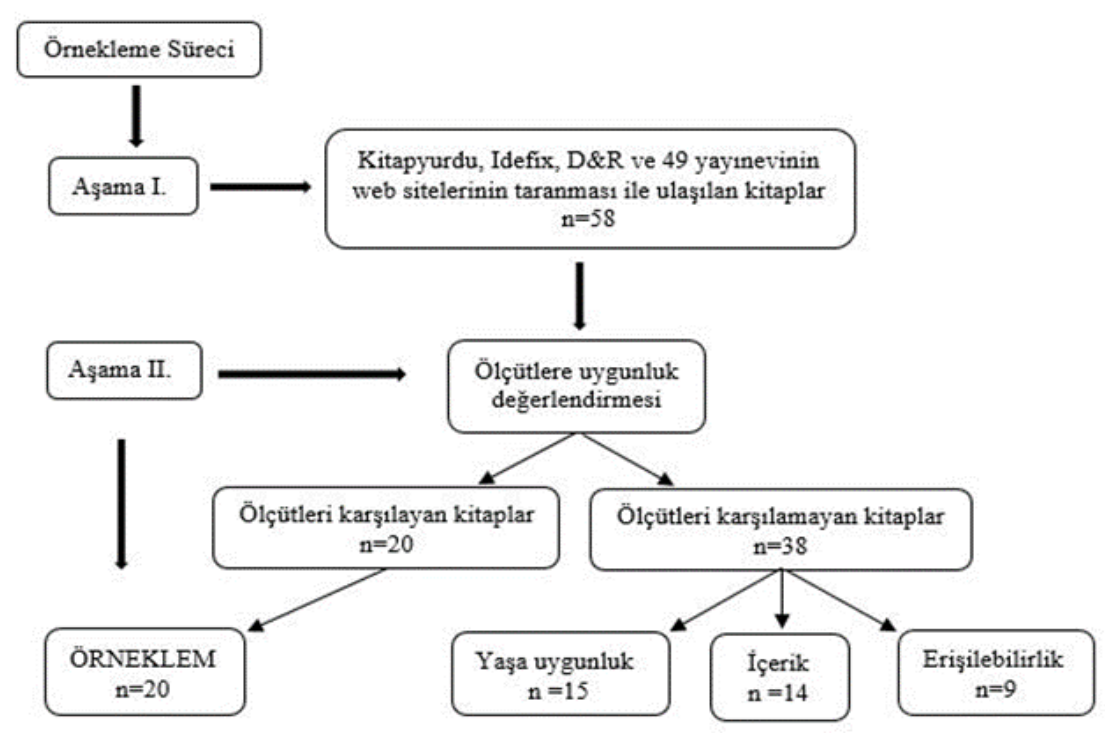

Şekil 1. Örnekleme Süreci

Çocuk kitaplarının belirlenmesinde Milli Eğitim Bakanlığı Okul Öncesi Eğitim Programının sınıflandırması dikkate alınmıştır (2013). Programda, özel gereksinimli çocuklar; zihinsel, görme ve işitme yetersizliği, ortopedik rahatsızlığı ve süreğen hastalığı, otizm spektrum bozukluğu (OSB), dikkat eksikliği ve hiperaktivite bozukluğu (DEHB), dil ve konuşma bozukluğu ve özel yetenekli olan çocuklar şeklinde sınıflandırımıştır (MEB, 2013). Bu sınıflandırma temelinde, "farklıık, farkındalık, özel gereksinim, yetersizlik, görme, işitme, ortopedik, hastalık, down, otizm, otistik, dikkat, hiperaktivite, zihinsel, zekâ, üstün yetenekli, yetenek, konuşma, dil" anahtar sözcükleri kullanılarak çocuk kitapları taranmıştır. İnternet üzerinde yapılan bu taramada, 3-6 yaş için yazıldığı bilgisi içeren, tanıtımı ya da başlığı anahtar sözcüklerle eşleşen, farklı yayınevleri tarafından basılmış 58 çocuk kitabına ulaşılmışır (Ek 1).

Örnekleme sürecinin ikinci aşamasında, ulaşılan kitapların yaşa uygunluk, içerik ve erişilebilirlik ölçütlerini karşılayıp karşılamadığı incelenmiştir. Yaşa uygunluk ölçütü açısından kitaplar değerlendirildiğinde bazı kitapların kapağında 7 yaş ve üstü yazmasına karşın okul öncesi döneme uyarlanabilir içerikte olduğu; bazılarının ise 3-6 yaş olmasına rağmen okul öncesi için uygun olmadığı görülmüştür. Bu yüzden kitabın verdiği yaş aralığı değil araştırmacıların incelemesi temel alınmış ve uygun görülmeyen 15 kitap örneklem dışında bırakılmıştır. İçerik ölçütü açısından değerlendirildiğinde ise 14 tane kitabın başlık ya da tanıtımı anahtar kelimelerden birini içermesine rağmen özel gereksinimli bireylerle ilgisiz olduğu görülmüştür. Erişilebilirlik ölçütüne göre ise dokuz tane kitap, satışının ve basımının durmuş olması nedeniyle elenmiştir. Örneğin, TÜBiTAK yayınları tarafından önceki yıllarda basılmış ancak artık baskısı yapılmayan kitaplara öğretmenlerin kolayca erişemeyeceği düşünülerek bu kitaplar örneklem dışında bırakılmıştır. Bu değerlendirmeler sonrasında bu temel ölçütleri karşılayan toplam 20 adet resimli çocuk kitabı örnekleme dâhil edilmiş; 38 adet kitap ise örneklem dışında bırakılmıştır.

\section{Değerlendirme Aracı ve Analiz}

Araştırma kapsamında örnekleme giren 20 kitap, Dolly Gray Çocuk Edebiyatı Ödülü ${ }^{2}$ için kullanılan "Çocuk Edebiyatında (Gelişimsel) Engelli Bireylerin Nitelikli Tasvirleri Derecelendirme Ölçeği" ile değerlendirilmiştir. Dolly Gray ödülü her iki yılda bir Amerika Birleşik Devletleri'nde Özel Çocuklar Konseyi (CEC) ve Otizm ve Gelişimsel Yetersizlik Biriminin (DADD) katkıları ile özel gereksinimli bireyleri içeren nitelikli çocuk ve gençlik kitapları için verilmektedir. Ödül alan eserler, 12 kişiden oluşan ve içinde yazarlar, çizerler, ebeveynler, gençler ve öğretmenlerin de olduğu bir komite

\footnotetext{
${ }^{2}$ Dolly Gray Children's Literature Award
} 
tarafından, 'Çocuk Edebiyatında (Gelişimsel) Engelli Bireylerin Nitelikli Tasvirleri Derecelendirme Ölçeğ $i^{3 \prime}$ (Prater ve Dyches, 2016; 2020) kullanılarak belirlenmektedir (Tablo 1).

Tablo 1'de görüldüğü üzere bu ölçek "genel etki, kişisel özellikler, sosyal etkileşimler, örnek uygulamalar, kardeş ilişkileri, bakış açısı, metnin edebi değeri ve resimleme" olmak üzere sekiz alt boyuttan oluşmaktadır. Değerlendirme aracındaki maddeler, kesinlikle katılıyorum (5) ve kesinlikle katılmıyorum (1) şeklinde Likert tipi derecelendirme ile puanlanmaktadır. Bazı alt bölümlerde de açıklayıcı ek sorular bulunmaktadır.

Tablo 1.

Çocuk Edebiyatında (Gelişimsel) Engelli Bireylerin Nitelikli Tasvirleri Derecelendirme Ölçeği ${ }^{4}$

\begin{tabular}{|c|c|c|}
\hline Alt Bölümler & $\begin{array}{l}\text { Puanlanan } \\
\text { Maddeler }\end{array}$ & $\begin{array}{l}\text { Açıklayıcı } \\
\text { Maddeler }\end{array}$ \\
\hline $\begin{array}{l}\text { A. Genel Etki (Kitabın okuyucuda bıraktığı etki, en beğenilen ve } \\
\text { beğenilmeyen yönü vb.) }\end{array}$ & 2 & 2 \\
\hline $\begin{array}{l}\text { B. Kişisel Tasvirler (Ayrımcı olmayan bir dil, benzerliklere vurgu, } \\
\text { güçlü yönlerin gösterimi vb.) }\end{array}$ & 6 & 8 \\
\hline $\begin{array}{l}\text { C. Sosyal Etkileşimler (Karakterin kabul düzeyi, sosyal ve } \\
\text { duygusal ilişkiler, sosyal katılım vb.) }\end{array}$ & 5 & 7 \\
\hline $\begin{array}{l}\text { D. Örnek Uygulamalar (Yararlanılan hizmetler, karakterin } \\
\text { tercihleri, toplumsal tutum vb.) }\end{array}$ & 5 & - \\
\hline $\begin{array}{l}\text { E. Kardeş iliş̧kileri (Olumlu ve olumsuz duygular, kardeşlerin } \\
\text { iliş̧ileri) (Eğer Varsa) }\end{array}$ & 5 & - \\
\hline F. Bakış Açısı (Hikâye kimin bakış açısı ile yazıımış, gerçekçi mi?) & 2 & 1 \\
\hline $\begin{array}{l}\text { G. Metnin Edebi Niteliği (Hikâyenin ilgi çekiciliği, yaşa uygunluk, } \\
\text { ortam tanımlaması vb.) }\end{array}$ & 5 & 2 \\
\hline $\begin{array}{l}\text { H. Resimleme (Canlılık, ruh halini yansıtma, yardımcı/adaptif } \\
\text { araçlar- eğer uygunsa- vb.) }\end{array}$ & 8 & - \\
\hline
\end{tabular}

Geçmiş yıllar içinde güncellenen bu değerlendirme aracı (Dyches ve Prater, 2005; Dyches, Prater ve Cramer, 2001; Dyches, Prater ve Leininger, 2009) çocuk ve gençlik kitaplarını değerlendiren çeşitli bilimsel çalışmalarda kullanılmıştır (Dyches vd, 2018; Leininger, Dyches, Prater ve Heath, 2010). Yapılan bu çalışmalarda değerlendirme aracının kişisel tasvirler, sosyal etkileşim, örnek uygulamalar ve kardeş ilişkileri alt bölümleri ortalamalar hesaplanarak puanlanmış, bu ve diğer bölümlerdeki açıklayıcı sorular ise kitapların genel özelliklerinin betimlenmesinde kullanılmıştır. Bu çalışmalarda kitapların niteliğini değerlendirmede metnin edebi niteliği ve resimleme alt bölümlerine ilişkin değerlendirmelere ise yer verilmemiştir.

Bu çalışma için araştırmacılar önce değerlendirme aracını geliştirenler ile çevrimiçi ortamda iletişime geçerek bu aracın puanlaması hakkında detaylı bilgi edinmişler ve aracı araştırmada kullanmak için izin almışlardır. Ödülde kullanılan aracın adı "gelişimsel engelli bireyler" ifadesi içermekle birlikte yapılan çalışmalarda genel olarak diğer engelleri olan bireyleri içeren kitapların değerlendirilmesinde de kullanılabileceği bildirilmiştir. İzin alındıktan sonra araç iki araştırmacı tarafından ayrı ayrı tercüme edilmiş, diğer iki araştırmacı tarafından bu tercümeler karşılaştırmış ve gerekli düzeltmelerin ardından aracın Türkçe formuna son hali verilmiştir. Aracın pilot uygulaması için örneklem dışında kalan dokuz farklı kitap değerlendirilmiş ve aracın çalışma kapsamında kullanılabileceğine karar verilmiştir (Ek 2). Bu araştırmada da önceki çalışmalarda olduğu gibi

\footnotetext{
${ }^{3}$ Araştırmada kullanılan bu araca https://www.dollygrayaward.com/ adresinden ulaşılabilir.

${ }^{4}$ Ödül komitesinde kullanılan araçtan farklı olarak bazı araştırmalarda değerlendirme aracının adı ve içeriğinden "gelişimsel" sözcüğü kaldırılarak genel olarak "engelli bireyler" ifadesi kullanılmıştır. Bu makale kapsamında ise açıklamalar yapılırken "özel gereksinimli bireyler" ifadesi tercih edilmiştir. Ayrıca, değerlendirme aracı standardize edilmediğinden makale kapsamında “ölçek" kavramı yerine "değerlendirme aracı" kullanılmıştır.
} 
değerlendirme aracının kişisel tasvirler, sosyal etkileşimler ve örnek uygulamalar alt bölümleri puanlamaya esas alınmıştır. Tüm kitaplarda kardeş karakterleri yer almadığından kardeş ilişkileri alt bölümünün puanları kullanılmamıştır. Değerlendirme aracının puanlamaya tabi tutulan alt bölümlerinden kitapların elde ettiği ortalama puanlar 1-2,5 aralığında ise olumsuz, 2.6-3,75 aralığında ise kabul edilebilir (nötr) ve 3.76-5,0 aralığında ise olumlu niteliklere işaret etmektedir (Ek 3). Değerlendirmeye tabi tutulan alt bölümlerden toplam puan da elde edilebilmektedir (Dyches vd. 2018; Leininger vd 2010; T.T. Dyches ve M. Prater, elektronik yazışma, Ekim, 2019). Bu çalışmada, değerlendirilen kitapların araçtan aldığı ortalama puanlar dikkate alınarak betimlemeler yapılmış ve karşılaştırmalarda eser sayısının azlığından dolayı yüzdelerden ziyade frekanslara başvurulmuştur. Değerlendirmeye dâhil edilmeyen alt bölümlerin puanlamaları ise güvenirliğin hesaplanmasında kullanılmıştır.

\section{Geçerlik ve Güvenirlik}

$\mathrm{Bu}$ araştırmanın güvenirliğine yönelik olarak farklı stratejilere başvurulmuştur. Buna örnek olarak örneklemdeki kitapların titizlikle analiz edilmesi, bulguların sunumunda doğrudan alıntılara ve resimlere başvurulması ve puanlayıcılar arası güvenirliğin hesaplanmasıdır. Araştırmacıların farklı kitapları benzer şekilde değerlendirerek analiz ettiğini ortaya koymak için "puanlayıcılar arası güvenirlik" formülü [görüş birliği/ (görüş birliği + görüş ayrılı̆̆ı)] kullanılmıştır (Miles ve Huberman, 2015). Araştırma kapsamında ulaşılan kitapların tamamı araştırmacılar tarafından önce okunmuş ve bağımsız olarak puanlanmıştır. Bu süreçte iki araştırmacı kitapların tamamını, diğer iki araştırmacı ise birbirlerinden ayrı 10 kitabı değerlendirme aracını kullanarak puanlamıştır. Böylece her kitap için üç tur puanlama yapılmıştır. Güvenirlik için kitapların değerlendirme aracının alt bölümlerinden elde ettiği ortalamalar ve madde puanları yüz yüze toplantılar yapılarak karşılaştırılmıştır. Görüş ayrılı̆ı gözlenen maddeler önce tartışılmış ve uzlaşma sağlanmışsa görüş birliği olarak kabul edilmiş; uzlaşma sağlanamayan maddeler ise görüş ayrılığı olarak kaydedilmiştir. Yapılan hesaplamalar sonucunda puanlayıcılar arası tutarılıı̆ın, tekil maddeler ve ortalama puanları üzerinde uzlaşma sağlanarak \%90 düzeyinde sağlandığı görülmüştür. $\mathrm{Bu}$ bağlamda, örnekleme dâhil olan kitapların değerlendirilmesinde puanlayıcılar arası güvenirliğin yüksek olduğu söylenebilir. Kitapların nitelikleri konusunda değerlendirme aracının alt bölümlerinden alınan puanlar hesaplanmış ve araştırmacıların uzlaştıkları olumlu, kabul edilebilir ve olumsuz değerlendirme sonuçlarına ulaşıımıştır (Ek 4).

\section{Etik Kurulu İzni}

Araştırma doküman incelemesi içerdiğinden etik kurul izni gerektirmemektedir. Bununla birlikte araştırma ve yayın etiği kurallarına uyulmuştur. Araştırmada kullanılan değerlendirme aracının sahibinden eposta ile yazışarak izin alınmış ve örnek resimlerin kullanılmasında kitaplarda yer alan telif uyarılarına dikkat edilmiştir. Bilgi sayfasında kaynak gösterilerek tanıtım için kısa alıntılar yapılmasına izin verdiği yazılı olan kitapların resimlerinden, telif haklarını ihlal etmeyecek düzeyde faydalanılmıştır. Yapılan alıntılarda kitap isimleri verilerek kaynak gösterilmiş ve ilk aşamada örneklemeye giren tüm kitapların listesi Ek-1'de sunulmuştur. Değerlendirilen kitapların elde ettikleri puanlar gizliliği sağlamak için kodlarla gösterilmiştir. Çalışma amaçları açısından düşük puanla olumsuz nitelikte bulunan kitaplar etik kurallar gereği açıklanmamıştır.

\section{Bulgular}

Özel gereksinimli karakterleri içeren 20 kitabın değerlendirilmesine dayalı bulgular, kitapların genel özellikleri, kişisel tasvirler, sosyal etkileşimler ve örnek uygulamalar temaları altında açıklanmıştır. Değerlendirme sonucunda ulaşılan bulgular kitaplardan alıntılar ve resimlerle desteklenerek aşağıdaki bölümlerde sunulmuştur. Kitapların genel ortalama puanlar açısından 12 tanesinin olumlu, 4 tanesinin kabul edilebilir ve 4 tanesinin olumsuz nitelikte olduğu bulgusuna ulaşılımışır. Olumlu ve kabul edilebilir nitelikte olan kitapların kapsayıcı eğitim felsefesine uygun olarak özel gereksinimli bireylere yönelik farkındalık geliştirmede kullanılabileceği belirlenmiş ve okul öncesi öğretmenleri için Ek-5’te bir öneri listesi sunulmuştur. 


\section{Özel Gereksinimli Karakter İçeren Kitapların Genel Özellikleri}

Özel gereksinimli karakter içeren kitapların genel özelliklerinde yayın bilgileri ile değerlendirme aracındaki açıklayıcı maddelerden ulaşılan bulgular açıklanmıştır. Tablo 2'de görüldüğü gibi açıklayıcı maddeler bazı demografik özelliklerden oluşmaktadır.

Tablo 2.

Değerlendirilen Kitapların Genel Özellikleri

\begin{tabular}{|c|c|c|c|c|c|c|c|c|c|}
\hline \multicolumn{3}{|c|}{ Kitabın } & \multicolumn{7}{|c|}{ Özel Gereksinimli Karakterin } \\
\hline Kodu & YIll & Dili & Grubu & Cinsiyet & K. Düzeyi & Yaşı & Ortamı* & Ailesi* & Durumu \\
\hline K1 & 2015 & Yb. & Zihinsel & KIz & Ana & illkokul & $\mathrm{E}-\mathrm{O}$ & $K / A / B$ & Mağdur \\
\hline K2 & 2011 & Yb. & S. Hastalık & Erkek & Ana & İlkokul & $\mathrm{S}$ & $A / B$ & Hiçbiri \\
\hline K3 & 2016 & Yb. & S. Hastalık & $\mathrm{K} 1 \mathrm{z}$ & Ana & illkokul & E-O-S & $K / A / B$ & Hiçbiri \\
\hline K4 & 2018 & $\mathrm{Yb}$. & OSB & Erkek & Ana & Okul öncesi & E-O-S & $\mathrm{K} / \mathrm{A} / \mathrm{B}$ & Hiçbiri \\
\hline K5 & 2018 & Yb. & OSB & Erkek & Ana & ilkokul & $\mathrm{E}-\mathrm{S}$ & K/A & Mağdur \\
\hline K6 & 2008 & Yb. & Ortopedik & Erkek & Ana & ilkokul & $\mathrm{E}-\mathrm{O}$ & $A / B$ & Hiçbiri \\
\hline K7 & 2015 & Tr. & Ortopedik & $\mathrm{K} 1 \mathrm{z}$ & Ana & Yok & E-S & A & Hiçbiri \\
\hline K8 & 2008 & Yb. & Ortopedik & Erkek & Yan & Yok & E-S & Diğer & Hiçbiri \\
\hline K9 & 2014 & Tr. & Ortopedik & Erkek & Yan & Yok & $\mathrm{E}-\mathrm{S}$ & Diğer & Hiçbiri \\
\hline K10 & 2015 & Yb. & Dil-Konuş. & Erkek & Ana & Okul öncesi & O-E-S & A & Hiçbiri \\
\hline K11 & 2018 & Tr. & İşitme & Erkek & Yan & Yok & E-S & B & Hiçbiri \\
\hline K12 & 2011 & Yb. & İşitme & $\mathrm{K} 1 \mathrm{z}$ & Ana & İlkokul & E-O-S & A & Hiçbiri \\
\hline K13 & 2016 & Yb. & Görme & $K_{1 Z}$ & Ana & illkokul & E-O-S & $K / A / B$ & Mağdur \\
\hline K14 & 2018 & Yb. & Ortopedik & KIz & Ana & İlkokul & $\mathrm{E}-\mathrm{O}$ & $K / A / B$ & Hepsi \\
\hline K15 & 2015 & Yb. & DEHB & Erkek & Ana & Yok & $\mathrm{E}$ & K/A/B & Suçlu \\
\hline K16 & 2013 & Tr. & DEHB & Erkek & Ana & İlkokul & E-O-S & A & Suçlu \\
\hline K17 & 2019 & Yb. & DEHB & Belirsiz & Ana & Yok & E-S & $A / B$ & Hiçbiri \\
\hline K18 & 2009 & Yb. & DEHB & Erkek & Ana & illkokul & E-O-S & $\mathrm{A} / \mathrm{K}$ & Suçlu \\
\hline K19 & 2011 & Yb. & S. Hastalık & Erkek & Yan & Yaşlı & $\mathrm{E}-\mathrm{S}$ & Diğer & Hiçbiri \\
\hline K20 & 2016 & Yb. & S. Hastalık & Erkek & Yan & Yaşı & E-S & Diğer & Hiçbiri \\
\hline
\end{tabular}

Ortam: $\mathrm{E}=\mathrm{Ev} ; \mathrm{O}=\mathrm{Okul}$; $\mathrm{S}=$ Park, bahçe, tatil yeri, sokak ve hastane gibi sosyal ortamlar.

Ailesi: K=Kardeş; A=Anne; B= Baba; Diğer: Diğer aile bireyleri

Değerlendirilen kitapların yayın bilgilerine göre özel gereksinimli karakter içeren eserler 2008-2019 yılları arasında yayınlanmış görülmektedir. Yayın yılı açısından 2008-2013 yılları arasında sadece yedi kitap varken 2014 yılından sonra yayınlanmış olanlar neredeyse iki kat fazladır (13). Diğer taraftan, tercüme kitapların sayısı oldukça yüksek olup Türkçe yazıımış olanların sayısı çok düşüktür. Bu kitaplardan 16 tanesi yabancı dilden tercüme edilmiş (Yb) 4 tanesi ise Türkçe ( $\mathrm{Tr}$ ) yazıımıştır. Kitaplarda yer alan özel gereksinimli karakterlerin yetersizlik grubuna bakıldığında en fazla ortopedik yetersizlik (5) ile dikkat eksikliği ve hiperaktivite bozukluğu (DEHB) (4) olduğu görülmüştür. En az ise görme yetersizliği, (1), zihinsel yetersizlik (1) ve dil ve konuşma bozukluğu (1) olan karakterlere yer verilmiştir. Süreğen hastalık (4) grubunda sınıflandırılan kitaplar sayıca yüksek görünse de bu kitaplarda bir astım, bir alerji iki tane de Alzheimer hastalığı (yaşı karakterler) yer almaktadır. Otizm spektrum bozukluğu (OSB) ve işitme yetersizliği gruplarında da kitap sayısının iki ile sınırlı olduğu söylenebilir. Bu bulgular özel gereksinimli karakterleri içeren kitaplarda farklı yetersizlik gruplarının yeterince temsil edilmediğine işaret etmektedir. Çoklu yetersizlikleri olanlar ile üstün zekâlı ve yetenekli karakterlere ise değerlendirmeye alınan çocuk kitaplarında rastlanmamıştır.

Cinsiyet özellikleri açısından incelendiğinde, değerlendirilen kitaplardaki özel gereksinimli karakterlerin çoğunluğunun erkek olduğu görülmüştür (13). Özel gereksinimli karakterlerin hayvan olarak resmedildiği üç kitapta da hayvan karakterlerin bir tanesi erkek, bir tanesi dişi, bir karakterin ise cinsiyeti belirsizdir. Özellikle, DEHB, otizm spektrum bozukluğu ve ortopedik yetersizlik türünde özel gereksinimli karakterlerin erkek olduğu görülmektedir. Cinsiyet dağılımı açısından gözlenen farklılıklar özel gereksinimli karakterlerin hikâyedeki kişileştirme düzeylerinde de mevcuttur. Özel gereksinimli bireyler bu kitaplarda daha çok ana karakter (15) olarak kişileştirilmiş olup yan karakter 
olarak işlenenlerin sayısı beş ile sınırlıdır. Örneğin, Yavaşla Pisican isimli kitaptaki yavru kedi hikâyenin ana karakteridir. Cemile Arkadaşına Yardım Ediyor isimli kitapta ise ortopedik yetersizliği olan Can ise yan karakterdir ve Cemile'nin onunla etkileşimi konu edilmiştir. Kişileştirme düzeyine paralel değerlendirilen diğer bir konu da özel gereksinimli karakterin kitaplardaki yeridir. Değerlendirilen kitaplarda özel gereksinimli karakterin varlığının hikâyeyi etkilemesi (12 ) ve bir yetersizliğin öğretilmesi (7) en sık rastlanan durumdur.

Kitapların çoğunda yaş açık olarak verilmemiş olsa da bazılarında hikâye örgüsü, kullanılan ifadeler ve okul ortamlarının resimlerinden çıkarımlar yapılmıştır. Örneğin Aleks çok Hassas isimli kitapta sınıf arkadaşı Aleks'e salıncakta sallanmayı teklif edince, Aleks, "Hayır Zoa, ben bulmaca çözmeyi tercih ederim" şeklinde cevap vermektedir. Bu ifadeden, çocuğun ilkokul yaşında olduğu anlaşılmaktadır. Üç kitapta yer alan hayvan karakterler de genel olarak yavru dönemlerde resmedilmiştir. Sonuç olarak incelenen kitaplarda özel gereksinimli karakterlerin 10 tanesi ilkokul, 3’ü okul öncesi, 2'si ise yaşlılık dönemindedir. Yaşa dair ipucu içermeyen diğer 6 kitapta ise karakterler çocuklardan veya yavru hayvanlardan oluşmaktadır. Değerlendirilen kitaplarda özel gereksinimli olup da orta yaşlı veya genç karakterlere yer verilmediği ve yaşlılık döneminde karakterler içeren kitapların düşük sayıda (2) olduğu gözlenmiştir.

Kitaplarda karakterlerin bulundukları ortamlara bakıldığında ise neredeyse tüm kitaplarda ev ortamına (19); çoğu kitapta (16) da sokak, park, spor sahası ya da tatil yeri gibi sosyal ortamlara yer verildiği görülmüştür. Okul ortamı kitapların sadece yarısında (10) resmedilirken kitapların çoğunda hikâyenin okul-ev veya ev-park gibi iki farklı ortama (12) yer verildiği görülmüştür. Sonuç olarak, değerlendirilen kitapların özel gereksinimli karakterin bulunduğu ortamlar açısından çeşitlilik içerdiği ifade edilebilir. Ancak kardeş ilişkileri açısından aynı çeşitlilik gözlenmemiş olup sadece sekiz kitapta kardeş ilişkilerine dair dolaylı çıkarım yapılabilecek etkileşimler mevcuttur. Kardeş ilişkilerine doğrudan yer veren tek eser Barış’ın Gezintisi isimli kitaptır. Ayrıca, özel gereksinimli karakterlerin anne ve babası gibi aile üyelerinin de kitaplardaki dağııımı farklı olup 10 kitapta baba karakterine, 15 kitapta anne karakterine, dört kitapta ise diğer aile bireylerine rastlanmıştır. Özel gereksinimli karakterlerin anne ve baba ile ilişkileri farklı işlenmiş olup özellikle baba ile etkileşimlerin bu kitaplarda sınırlı olduğu görülmüştür. Ölçme aracının alt başlıklarına göre olumlu nitelikte bulunan kitaplarda aile bireyleri özel gereksinimli karakter ile genellikle olumlu etkileşimler içinde resmedilmiştir.

Özel gereksinimli bireylerin durumu açısından incelendiğinde bazı kitaplarda karakterleri, mağdur (3), suçlu (3), ya da hem suçlu hem de mağdur (1) olarak nitelendiren ifadelere rastlanmıştır. Karakterleri mağdur ya da suçlu olarak nitelendiren kitapların dört tanesi değerlendirme aracından aldıkları puana göre "olumsuz" iki tanesi ise "kabul edilebilir" nitelikte bulunan kitaplardır. Örneğin, kabul edilebilir nitelikte bulunan Anyes'in Sakarlıkları isimli kitapta, "Hayır, Anyes'i takımımızda istemiyoruz! Onun yüzünden oyunu kaybedeceğiz" ifadesi akranları tarafından dışlanan karakterin mağduriyetine işaret etmektedir. Benzer şekilde suçlu betimlemesi içeren kitaplarda da karakterlerin etrafı dağıtma ve eşyalara zarar verme gibi abartılı davranışları vurgulanmıştır. Olumlu nitelikte bulunan kitaplarda ise özel gereksinimli karakterleri suçlu ya da mağdur şeklinde betimleyen ifadelere rastlanmamıştır.

Değerlendirme aracına göre "olumlu" ve "kabul edilebilir" nitelikte bulunan eserlerin metin ve resim gibi biçimsel özellikler açısından da olumlu özelliklere sahip olduğu gözlenmiştir. Bu eserlerin okul öncesi dönem çocukları için dikkat çekici olduğu ve akla yatkın olay örgüleri içerdiği görülmüştür. Metnin edebi niteliği açısından, Farklı ama Aynı ve Seslerin Perisi ışık adlı kitaplar örnek verilebilir. Olumlu veya kabul edilebilir nitelikte bulunmakla birlikte bazı eserlerin uzun bir metin ve didaktik bir anlatım içerdiği de görülmüştür. Bu konuda, Duyamamak Böyle Bir Şey isimli kitap örnek verilebilir. Bu eserlerin özel gereksinimli bireylerin bakış açısından yazılması ve kitap sonunda özel gereksinim grubu hakkında ek bilgiler ve etkinlikler içermesi olumlu değerlendirilmesine karşın farkındalık geliştirme çalışmalarında bu eserleri kullanırken bir takım değişikliklere ihtiyaç duyulabileceği görülmüştür. Resimleme açısından da bu kitapların çoğunda çizimler ve görsel anlatımın nitelikli ve okul öncesine uygun olduğu görülmüştür (Resim 1-2). 


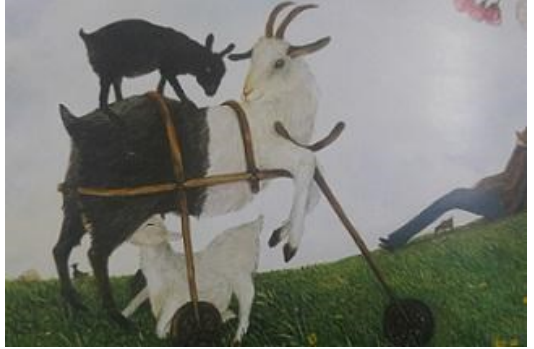

Resim 1. Farklı ama Aynı

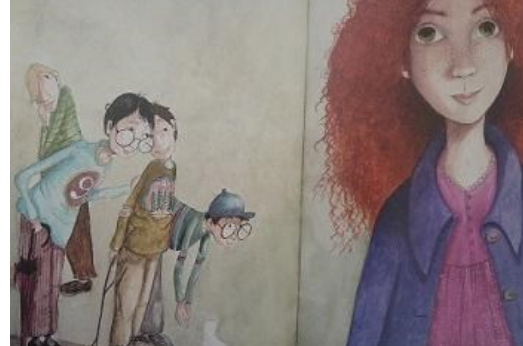

Resim 2. Seslerin Perisi Işık

Özellikle içeriğinde yardımcı/adaptif teknolojiler olan yedi kitapta bu araçlar doğru, gerçekçi ve çağdaş bir şekilde resmedilmiştir. Resim 1'de görülen Farklı ama Aynı isimli kitap yardımcı teknolojilerin kullanımına örnek verilebilir. Belirli bir hikâye örgüsü içeren kitapların da anlatımı destekleyen resimler içerdiği ve sanatsal çizimlerle diğerlerinden ayrıldığı gözlenmiştir. Bu kitaplardaki resimler, karakterlerin özelliklerini ve ruh hallerini de gerçekçi olarak yansıtmaktadır. Bu açıdan, Resim 2'de görülen Seslerin Perisi Işık isimli kitap resimleme özellikleri ile olumlu örnekler arasında gösterilebilir.

\section{Özel Gereksinimli Karakterlerin Kişisel Tasvirleri}

Özel gereksinimli karakter içeren kitapların kişisel tasvirler açısından niteliği altı madde ile puanlanmıştır. Bu maddeler, "ayrımcı olmayan bir dil kullanılması, benzerliklerin vurgulanması, güçlü yönlerin gösterilmesi, gelişmiş özelliklerine yer verilmesi, gerçekçi tanımlanması, karakterin doğru ifade edilmesi" şeklinde özetlenebilir. Kişisel tasvirler açısından eserler değerlendirildiğinde 14 tane olumlu, 2 tane kabul edilebilir ve 4 tane olumsuz niteliğe sahip olan kitap bulunmuştur. Karakterlerin kişisel tasvirleri açısından olumlu nitelikte bulunan kitaplara, Greg'in Zaferleri isimli kitap örnek verilebilir.

Değerlendirme aracının alt madde puanlamalarına bakıldığında kişisel tasvirler açısından olumlu niteliklere sahip olduğu belirlenen kitaplarda çoğunlukla özel gereksinimli karakterlerin gerçekçi ve doğru bir şekilde tanımlandıkları, güçlü ve gelişmiş yönlerinin gösterildiği ve ayrımcı olmayan bir dil kullanıldığı görülmüştür. Ancak, özel gereksinimli karakterlerin diğer karakterlerle benzerlikleri ise daha az vurgulanmıştır. Özel gereksinimli karakterlerin güçlü yönlerinin gösterilmesine Greg'in Zaferleri isimli kitapta dil ve konuşma bozukluğu olan karakterin kendini resimlerle anlatması örnek gösterilebilir (Resim 4). Sınıf öğretmeni, Greg'in güçlü yönlerinden biri olan resim yapmasını pekiştirmiş ve bu şekilde kendini ifade etmesini desteklemiştir. Burada, özel gereksinimli karakterin akranları ile iletişim kurabilmek ve oyun oynayabilmek için özgün yollar bulduğu ve bunun da sınıf topluluğu tarafından benimsendiği görülmektedir. Karakterlerin gelişmiş özelliklerine yer verilmesine Dedemin Müziği isimli kitapta Alzheimer hastası karakterin piyano çalması örnek verilebilir. Bu kitapta geçen çocuk karakterin, "Dedemin parmaklarının notaları hatırlamak için ışığa ihtiyacı yoktu" ifadesi bu özelliğe işaret etmektedir. Benzerliklerin vurgulanması konusunda en iyi örnek olarak, Şuşu, Can ve Dörtteker isimli kitap verilebilir. Bu kitapta ortopedik yetersizliği olan özel gereksinimli karakterin diğer akranı gibi tekerlekli araçlara binebileceği ve arkadaşı ile oynayabileceği işlenmiştir (Resim 5).

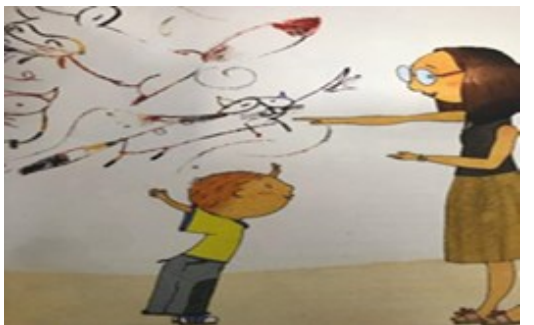

Resim 4. Greg'in Zaferleri

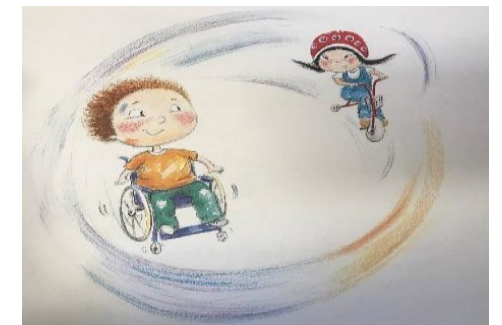

Resim 5. Şuşu, Can ve Dörtteker 
Kişisel tasvirler açısından olumsuz nitelikte bulunan kitaplara bakıldığında ise abartılı derecede olumsuz ifadeler ile farklııklar ve zayıflıkları vurgulayan bir dil kullanımının hâkim olduğu gözlenmiştir. Bu kitaplarda, hayvanlara eziyet etme, oyuncak bebekleri parçalama, eşyalara zarar verme, gürültü, kurallara aykırı hareket etme gibi davranışlar ve özel gereksinimli karakterlere yönelik sakar, beceriksiz, haylaz, tembel, aptalca ve dikkatsiz gibi olumsuz tasvirlere rastlanmıştır. Örneğin, K18 kodlu kitapta özel gereksinimli karakterin kıyafetlerini ters giymesi üzerine kardeşinin, "Abi yaa, bu halinle Çin malı pelüş tavşanlara benziyorsun!" tepkisi, karakterin zayıf yönünü alaycı bir ifade ile tasvir etmektedir. Kitapta geçen "dikkatsiz" sözcüğü de özel gereksinimli karakterin kişiliğine yöneltilmiş olumsuz bir etiket niteliğindedir. Sınıfta meydana gelen bir kaza sonrası öğretmenin kullandığı, "Oğlum neden dikkat etmiyorsun? Bak her taraf berbat oldu!" ifadeleri de bu etiketi pekiştirmektedir.

\section{Özel Gereksinimli Karakterin Sosyal Etkileşimleri}

Değerlendirilen kitaplarda sosyal etkileşimler, özel gereksinimli karakterlerin aile, akranlar, uzmanlar ve diğerleri ile gündelik yaşamdaki ilişkileri ve etkileşimlerine odaklanmaktadır. Sosyal etkileşimler beş madde ile puanlanmaktadır. Bu doğrultuda, "çoklu sosyal ilişkilere yer verilmesi, kabul edildiklerinin gösterilmesi, sosyal katkılarının gösterilmesi, empatinin desteklenmesi ve saygı duyulması" şeklinde özetlenebilecek maddelerden alınan ortalama puanlara bakıldı̆ı̆ında kitapların 13 tanesi olumlu, 4 tanesi olumsuz, 3 tanesi ise kabul edilebilir nitelikte bulunmuştur. Özel gereksinimli karakterlerin sosyal etkileşimleri açısından olumlu niteliğe sahip kitaplara "Bende Astım Var" isimli kitap örnek verilebilir.

Özel gereksinimli karakterlerin sosyal etkileşimlerine yönelik yapılan değerlendirmeye maddeler bazında bakıldığında ise olumlu nitelikte bulunan kitapların özel gereksinimli karakteri kabul edilen, saygı duyulan, merhameti değil empati geliştirmeyi destekleyen bireyler olarak betimlediği görülmektedir. Değerlendirilen kitaplarda, özel gereksinimli karakterlerin olumlu sosyal katkıları yani diğer karakterlerin gelişimine katkı sağlaması ve çoklu sosyal ilişkiler daha az sıklıkta rastlanan sosyal etkileşim özellikleridir. Özel gereksinimli karakterleri farklı bireylerle karşılıklı sosyal ilişkiler içinde gösteren sosyal ilişkilere örnek olarak Bende Astım Var isimli kitaptan, "O günden sonra tıpkı benim gibi astım hastası pek çok çocukla tanıştım (...) Hala takımımda futbol oynuyorum" ifadeleri verilebilir. Bu örnekteki özel gereksinimli karakter, özel gereksinimli olan ve olmayan farklı akranlar ile sosyal ilişkiler kurmuş görünmektedir. Ayrıca, hastalığın bir futbol takımının üyesi olmayı engellemediğini vurgulayarak takımdaki akranlarının da gelişimine katkıda bulunmaktadır. Kabul edilme ve saygı öğelerine ilişkin olarak da Sara'ya Fındık Yok isimli kitapta besin alerjisi olan bir çocuk için mahalle kasabının özel bir sosis yapması yer almaktadır. Sara'nın annesinin, "kasabımızın senin için hazırladığı yeni tarif! Onlara Sara'nın sağlıklı sosisleri adını vermiş" ifadeleri süreğen hastalığı olan bir karakterin kabul edildiğine ve saygı duyulduğuna işaret etmektedir (Resim 7). Son olarak, işitme yetersizliği olan karakterle gülümseyerek iletişim kurmayı keşfeden bir kız çocuğunun bu tutumu sosyal etkileşimlerde empatinin desteklenmesine örnek gösterilebilir. Kız çocuğu, işitme yetersizliği olan bir çocuk için üzülerek merhamet duyguları ile hareket etmektense, gülümseme dili ile onunla iletişim kurmuş ve beraber oynamaya başlamışlardır (Resim 8).

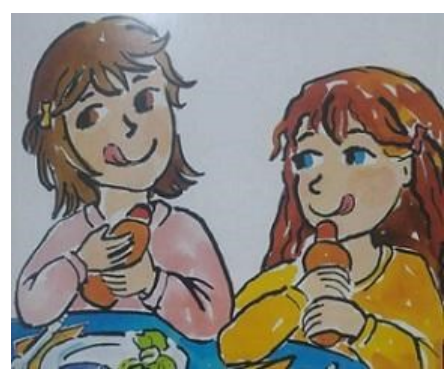

Resim 7. Sara'ya Fındık Yok

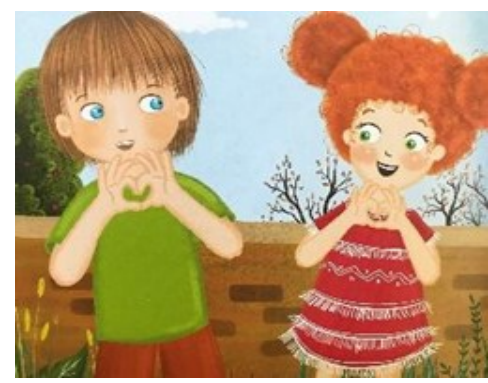

Resim 8. Gülümsemek İyidir 
Sosyal etkileşimler açısından olumsuz nitelikte bulunan kitaplara bakıldığında ise özel gereksinimli karakterlerin yalıtılmış ortamlarda ve sınırlı sosyal ilişkiler içinde gösterildiği ve zaman zaman da akranları tarafından alay edildiği veya kardeşleri tarafından azarlandığı görülmektedir. Örneğin, K16 kodlu kitapta özel gereksinimli karakter, ev içinde ve dışında hep tek başına oynarken resmedilmiştir. Kitapta bu karakterin diğer çocuklarla sözlü iletişimini içeren bir cümleye rastlanmamıştır. Diğer çocukların resmedildiği iki sayfadaki şu ifadeler bu bulguyu desteklemektedir: O, " öğretmenini hiç dinlemiyordu. Yerinden kalktı ve pencereden dışarıyı seyretmeye başladı. Sınıftaki ve bahçedeki arkadaşları şaşkınlıkla ona baktılar." Bu kitaptaki özel gereksinimli karakterin yegâne ilişkisi ebeveyn, öğretmen veya uzman rolündeki yetişkinlerle olup onların etkileşimlerinin de hesap sorma, yönlendirme ve sorgulama temelli olduğu gözlenmiştir.

\section{Özel Gereksinimli Karakterin Deneyimlediği Örnek Uygulamalar}

Özel gereksinimli karakterlerin toplumda deneyimlediği örnek uygulamalar aile dışındaki farklı kurumların sunduğu fırsatlar ve profesyonel hizmetleri kapsamakta olup toplumsal yapı içinde özel gereksinimli bireylerin bunlardan faydalanma ve tercihte bulunabilme durumlarını içermektedir. Bu doğrultuda değerlendirme aracında örnek uygulamalar açısından kitapların niteliği, "vatandaşlık haklarına eşit erişim, özel gereksinimli bireye uygun hizmetlerden yararlanma, meslek edinme, herkes gibi seçim yapabilme, özel gereksinimli bireylere yönelik tutum ve uygulamalarda döneme uygunluk" şeklinde özetlenebilecek 5 madde ile belirlenmektedir. Örnek uygulamalar bölümünden kitapların aldığı ortalama puanlar değerlendirildiğinde 6 tane kitabın olumlu, 9 tanesinin kabul edilebilir, 5 tanesinin ise olumsuz nitelikte olduğu tespit edilmiştir. Özel gereksinimli karakterlerin deneyimlediği örnek uygulamalar açısından olumlu nitelikte bulunan kitaplara, Büyükbabam Değişti isimli kitap örnek verilebilir.

Örnek uygulamalar açısından yapılan değerlendirmeye maddeler bazında bakıldığında özel gereksinimli karakterlerin yaş, ilgi ve becerilerine uygun hizmetlerden faydalanması kitaplarda en az rastlanan deneyimdir. Ayrıca, kitapların hiçbirinde meslek edinme ve istihdam süreçlerine yer verilmemiştir. Sadece bir kitapta karakterin gelecek hayalleri kapsamında meslek edinmeye değinilmiştir. Diğer taraftan, olumlu nitelikte bulunan kitaplar hikâye örgüsü içinde, özel gereksinimli bireylerin çeşitli toplumsal fırsatlar ve hizmetlerden ilgi ve yetenekleri doğrultusunda faydalanmalarına ve seçimler yapabilmelerine yer vermiştir. Örneğin, Büyükbabam Değişti isimli kitapta Alzheimer hastası karakterin unutkanlık için doktora gittiği ve torunları ile gölde balık tuttuğu anlatılmıştır. Bu kitaptaki özel gereksinimli karakter, sağlık hizmetleri ve boş zamanı değerlendirme gibi önemli vatandaşlık haklarından kendi tercihleri doğrultusunda faydalanmaktadır. Duyamamak Böyle Bir Şey isimli kitapta işitme yetersizliği olan karakterin, "Belki bir doktor ya da bir avukat olurum. Belki de Thomas Edison gibi bir şey icat ederim" ifadesi meslek edinmenin önünde engel olmadığına vurgu yapmaktadır. Ayrıca, bu karakterin okulda öğretmeninin desteği ile İşaret Dili Kulübü kurması ve öğretmeninin konuşurken özel bir mikrofon kullanması uygun hizmetlerden faydalanma, herkes gibi seçimler yapma ve özel gereksinimli bireylere yönelik tutum ve uygulamalarda döneme uygunluk konularında iyi örnekler arasında gösterilebilir. Aleks çok Hassas adlı kitapta da özel gereksinimli karakterin toplumda deneyimlediği örnek uygulamalar çeşitlilik göstermektedir. Resim 11'de Aleks ailesi ile tatile gitmiş ve şemsiyenin altında kumsalın tadını çıkarmaktadır.

Örnek uygulamalar kapsamında kabul edilebilir nitelikte bulunan kitaplardan Anyes'in Sakarlıkları ve Yapabilirim isimli kitaplar fırsatlara erişim veya uygun hizmetlerden ziyade özel gereksinimli bireyin göstereceği performans veya üstün çabaya odaklanmışlardır. Örneğin, ortopedik yetersizlik grubunda değerlendirilen Anyes'in, "Annem, babam ve Luiz Hanım artık benimle gurur duyuyor, beni eleştirmiyorlar. Yaratıcı ve sebatkâr olduğumdan söz ediyorlar" ifadesi faydalanılan hizmetten ziyade bireyin bu hizmetle ulaştığı sonucu vurgulamaktadır (Resim 12). Yapabilirim isimli kitapta ise ortopedik yetersizliği olan çocuk "diğer çocuklar gibi olmak" ve onlarla oynayabilmek için tekerlekli sandalyesini çok iyi kullanması gerektiğini düşünmüş ve "O kadar çalıştım ki ellerim su toplamasın diye eldiven takmaya başladım" ifadeleri ile bu üstün çabaya işaret etmiştir. 


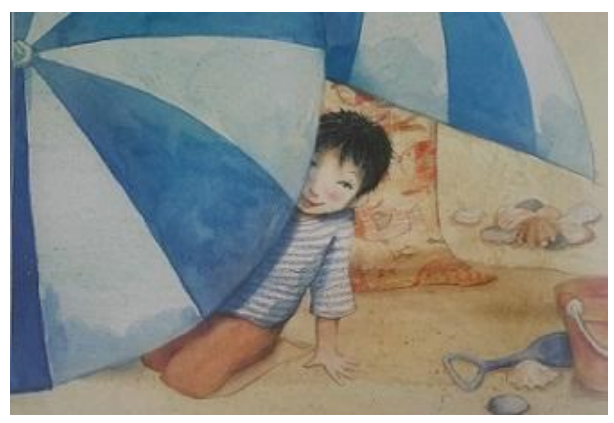

Resim 11. Aleks çok Hassas

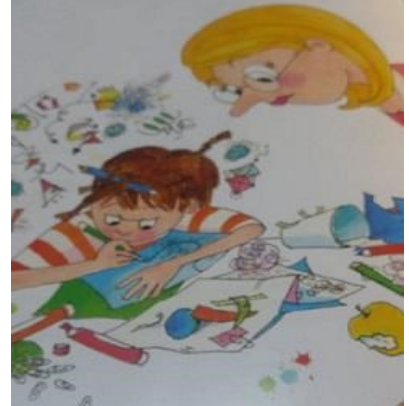

Resim 12. Anyes'in Sakarlıkları

Toplumda deneyimledikleri örnek uygulamalar açısından olumsuz nitelikteki kitapların da özel gereksinimli karakterleri, çoğunlukla ev ortamında geçen olay örgülerine yerleştirdiği ve vatandaşlık hakları, farklı kaynakların kullanımı, herkes gibi tercihlerde bulunma, uygun hizmetlerden yararlanma gibi toplumsal fırsatlara yeterince yer vermediği görülmüştür. Örneğin, K15 kodlu kitapta özel gereksinimli karakter sabaha karşı gürültü yapıp tüm evi dağıtınca sakinleşmesi için "annesinin kolları arasında hapsedilmişti." Bu örnekte de görüldüğü gibi özel gereksinimli karakterler, olumsuz değerlendirilen kitaplarda genellikle toplum yaşamından soyutlanmış ve ev ortamını vurgulayan hikâye örgülerine konu olmuşlardır.

\section{Tartışma ve Sonuç}

Özel gereksinimli bireylerin evrensel hakları temelinde toplumla bütünleşmiş bir yaşam sürmeleri okullarda erken yıllardan itibaren bu bireylere yönelik farkındalık geliştirilmesi ile mümkün olabilir. Bu açıdan özel gereksinimli karakterler içeren nitelikli çocuk kitapları önemli bir araç olup kapsayıcı eğitim bağlamında öğretmenlerin sınıf içi etkinliklerde kullanmaları için bu eserlere erişiminin sağlanması gerekmektedir (Favazza, LaRoe, Phillipsen ve Kumar, 2000; Ostrosky vd, 2015). Mevcut koşullarda, okul öncesi öğretmenlerinin özel gereksinimli bireylerle ilgili sınıftaki çocuklara daha çok konuşarak bilgi verdikleri ve çocuk kitaplarını yeterince kullanmadıkları görülmektedir (Ağgül-Yalçın ve Yalçın, 2018; Yıldız ve Arıkan, 2019). Öğretmenlerin bu yönelimlerini özel gereksinimli bireyleri konu alan yeterli sayıda çocuk kitabı olmaması açıklayabilir. Nitekim Işıtan, 1990 ve 2015 yılları arasında özel amaçlı çocuk kitaplarını araştırmış ve özel gereksinimlilik konusunda sadece 10 kitap olduğunu bildirmiştir (2016). Gönen ve diğerleri (2018) de benzer sonuca ulaşmakla birlikte 2011 yılından itibaren bu konuyla ilgili çocuk kitaplarının arttığına dikkat çekmişlerdir. Özel gereksinimli karakter içeren çocuk kitaplarının sayısı son yıllarda artmış olsa da bu kitapların önemli bir kısmı tercüme eserlerdir. Üstelik hem Türkçe hem de yabancı eserlerin bazılarında özel gereksinimli karakterler halâ "sorunlu", "mağdur" veya "bakıma muhtaç" şekilde betimlenebilmektedir (Dyches, Prater ve Leininger, 2009; Dyches vd., 2018; Kaymaz, 2017). Buradan hareketle gerçekleştirilen bu çalışmada öğretmenlerin kolay erişebileceği ve özel gereksinimli karakterler içeren çocuk kitaplarının nitelikleri genel özellikler, kişisel tasvirler, sosyal ilişkiler ve örnek uygulamalar açısından çok boyutlu olarak betimlenmiştir.

Doküman inceleme modelinde yürütülen mevcut çalışmada, seçilen kitapların içerikleri kapsayıcı eğitim felsefesine uygun bir değerlendirme aracı ile analiz edilmiştir. Bulgular, kitapların genel özellikleri, özel gereksinimli karakterlerin kişisel tasvirleri, sosyal etkileşimleri ve örnek uygulamaları açısından olumlu veya kabul edilebilir nitelikte bulunan eserlerin farkındalık geliştirmede okul öncesi öğretmenleri tarafından kullanılabileceğine işaret etmektedir. Genel olarak, olumlu nitelikteki kitaplarda özel gereksinimli karakterlerin diğer bireylerin sahip olduğu haklara erişebildiği, sosyal katılımlarının yüksek olduğu, ailesi ve sosyal çevresi tarafından kabul gördüğü görülmüştür. Olumsuz nitelikte bulunan kitaplarda ise karakterlerin suçlu veya mağdur algısı oluşturan tasvirlerine başvurularak dışlanma, etiketlenme, sosyal soyutlanma gibi deneyimlerine rastlanmıştır. Kabul edilebilir nitelikteki kitaplarda ise içerik genel olarak olumlu olmakla birlikte uygun olmayan sözcüklerin kullanımı, farklııklara odaklanma ve toplumsal yaşamda yeterince etkin rollerde olmama gibi özellikler gözlenmiştir. Bu değerlendirmelere dayalı olarak olumlu veya kabul 
edilebilir nitelikte bulunan çocuk kitaplarından okul öncesi öğretmenleri için bir öneri listesi hazırlanmıştır (Ek 5). Farklı yetersizlik gruplarını içeren bu kitapların çoğunluğu tercüme eserler olup sadece üç kitap Türkçe yazılmıştır. Oluşturulan bu listeden altı tane kitabın değerlendirmeye tabi tutulan tüm özellikler açısından olumlu niteliklere sahip olduğu (listede yıldız ile gösterilen), diğerlerinin ise bazı uyarlama ve değişikliklerle kullanıldığı takdirde farkındalık çalışmalarında amaca ulaşılabileceği sonucuna ulaşılmıştır. Öğretmenler bu kitapları çocuklarla okurken uygunsuz ifadeleri atlama, uzun görülen metinleri kısaltma, karakterlerin ilişkileri ve davranışlarına eklemeler yapma gibi uyarlamalara başvurabilirler. Özetle, farklı yetersizlik gruplarının düşük sayıda temsili, Türkçe yazılmış kitapların azlığı ve bazı kitaplar için duyulan uyarlama gereksinimi özel gereksinimli karakter içeren okul öncesi çocuk kitapları konusunda önemli bir boşluğa işaret etmektedir.

$\mathrm{Bu}$ araştırmada değerlendirilen kitapların genel özelliklerine bakıldığında, gelecekte yazılacak çocuk kitaplarının daha nitelikli olmasına katkı sağlayacak yönde bulgulara ulaşıımıştır. Öncelikle, özel gereksinimli karakter içeren kitapların sayısı zamanla artmasına karşın toplamda az sayıda kitaba erişilebilmesi dikkat çekicidir. Bu durum, alanyazında işaret edilen özel gereksinimli karakterleri içeren kitapların azlığı sorununun halen devam ettiğini göstermektedir (Işıtan, 2016; Kaymaz, 2017; Vuran, 2014). Değerlendirilen kitapların çoğunluğunu tercüme eserler oluştururken Türkçe yazılmış olanların sayısı oldukça düşüktür. Başka bir dilden tercüme edilmiş kitaplar çocuklara farklı kültürel ve evrensel değerler konusunda zengin öğrenme fırsatları sunmakla birlikte (Mert, Albayrak ve Serin, 2013), ağılıklı olarak bu eserlere dayalı çalışmalar yapmak okul öncesi dönemde çocukların dikkatini özel gereksinimli bireyler konusundan günlük yaşamda aşina olmadıkları durumlara yöneltebilir. Örneğin, kitaplarda geçen yabancı isimler, teknik terimler, fiziksel olarak farklı ev veya eğitim ortamları ve tercüme ile değişen ifade biçimlerine odaklanan çocuklar özel gereksinimli karakterlerin hikâyelerinden uzaklaşabilir. Bazı eğitimcilerin çocuk kitaplarını seçerken yazar ve yayınevi bilgisini önemsemediği de dikkate alındığında (Yükselen, Yumuş ve Işık, 2016) kendi dilimizde yazılmış nitelikli kitapların sayısının artması hem özel gereksinimli bireylere yönelik farkındalığın geliştirilmesine katkı sağlayacak hem de okul öncesi dönem çocuklarının dil gelişimlerini destekleyecektir.

Değerlendirilen kitaplarda en fazla ortopedik yetersizlik ile DEHB grubunda özel gereksinimli karakterlere yer verilmiştir. Zihinsel yetersizlik, dil ve konuşma bozukluğu gibi aslında sık rastlanan gruplarda ise birer veya ikişer kitap olup çoklu yetersizliği olanlar ile üstün zekâlı ve üstün yetenekli karakterleri içeren kitaplara ise rastlanmamıştır. Olumsuz nitelikte bulunan kitapların daha çok DEHB grubunda yazılmış eserler olduğu görülmüştür. Cinsiyete yönelik bulgular da kitaplarda özel gereksinimli karakterlerin, özellikle DEHB, OSB ve ortopedik yetersizlik grubunda, çoğunlukla erkeklerden oluştuğunu göstermiştir. Farklı yetersizlik gruplarının temsili ve cinsiyet dağılımı açısından alan yazındaki çeşitli araştırmalar da benzer sonuçlara ulaşmışlardır (Gönen vd, 2015; Nelson ve Nelson, 2016; Leininger vd., 2010). Sonuç olarak çocuk kitaplarında farklı yetersizlik gruplarının yeterince temsil edilmediği ve mevcut durumun resmi istatistiklerde verilen oranlardan uzak olduğu söylenebilir. Nitekim Engellilerin Sorun ve Beklentileri Araştırması (2010), Türkiye'de 0-6 yaş arasında en fazla görülen yetersizlik alanlarının dil ve konuşma bozukluğu (\%25), işitme yetersizliği (\%9) ve zihinsel yetersizlik (\%7) olduğunu ortaya koymuştur. Aynı araştırmada farklı yetersizlik gruplarında kadınların oranları $\% 33$ ve \% 46,5 arasında, erkeklerin oranları da $\% 53,5$ ve \% 67,9 arasında değişmektedir (TÜiK, 2010). Bu araştırmanın bulguları cinsiyet dağııımı açısından TÜiK istatistiklerine yakın olsa da kitaplarda her yetersizlik grubunda farklı cinsiyetlere yer verilmesi çocukların özel gereksinim temelinde kadın veya erkeklere yönelik kalıp yargılar geliştirmelerini engelleyebilir (Nelson ve Nelson, 2016).

$\mathrm{Bu}$ çalışmada özel gereksinimli karakterlerin çocuk kitaplarında daha çok ana karakter düzeyinde kişileştirildikleri ve kitapların odağında bir yetersizliğin öğretildiği ve karakterlerin varlıkları ile hikâyeyi etkiledikleri görülmüştür. Özel gereksinimli karakterlerin yaşı açısından da kitaplar çoğunlukla okul çağı çocuklarını içermiş; genç veya orta yaş döneminde olan karakterlere ise yer verilmemiştir. Yaşılık dönemindeki karakterlere ise sadece iki kitapta rastlanmıştır. Farklı yaşlardan özel gereksinimli bireylerin yan karakter olarak temsillerine de kitaplarda yer verilmesi çocuklarda öğretici olmayan yollarla olumlu tutumlar geliştirilmesine katkı sağlayabilir. Ayrıca kitaplarda özel gereksinimli karakterlerin varlıkları ile hikâyeyi etkilemeyen konumlara sahip olması kapsayıcı eğitim 
felsefesine daha uygun görünmektedir. Bu şekilde, Karatay'ın (2011) vurguladığı karakter oluşturma konusunda çoklu tanımlamalarla derinlik sağlamak ve bir özelliğin aşırı vurgulanmasının önüne geçmek mümkün olabilir (Akt. Karataş, 2014). Son olarak farkındalık geliştirme konusunda öneri listesinde yer bulan eserlerin metin ve resimleme gibi özellikler açısından da diğer kitaplardan ayrıldığı gözlenmiştir. Genel olarak, değerlendirilen kitaplardaki resimler ve metnin uyumlu olduğu bulgusu Yıldız, Yazıcı ve Durmuşoğlu (2016) tarafından yapılan araştırmanın bulguları ile örtüşmektedir. Özellikle didaktik nitelikte olmayan kitaplarda farklı resim sanatları kullanılmış ve tüm sayfayı kaplayan resimlere başvurulmuştur. Ayrıca, kullanımı gerekli olan yetersizlik gruplarında yardımcı/adaptif teknolojilerin resimlerine de yer verildiği görülmüştür. Uzun ve didaktik olmayan anlatımları ve nitelikli resimleme özellikleri ile diğerlerinden ayrılan bu eserler okul öncesi dönemde çocukların dikkatlerini canlı tutacağından genel olarak kitaplara yönelik de olumlu tutumlar geliştirmelerine ve özel gereksinimli karakterlerle ilişki kurmalarına destek olabilir (Çiftçi, 2013; Şahin, 2014; Sever, 2013; Turan ve Ulutaş, 2016).

Araştırmada değerlendirilen çocuk kitaplarında özel gereksinimli karakterlerin kişisel özellikleri çoğunlukla olumlu tasvir edilmiştir. Karakterlerin özel gereksinimleri gerçekçi ve doğru tanımlanmış; güçlü ve gelişmiş yönleri ise ayrımcı olmayan bir dille açıklanmıştır. Uluslararası alan yazın da özel gereksinimli bireylere ilişkin toplumdan soyutlanan "zavallı, kusurlu" anlayışından toplumla bütünleşen etkin bir birey anlayışına doğru bir değişimin olduğuna işaret etmektedir. Diğer taraftan, kitaplarda özel gereksinimli karakterlerin diğerleri ile benzerliklerine daha az rastlanmıştır. Bu bulgular ulusal ve uluslararası alan yazınla örtüşmekle birlikte halen bazı kitaplar olumsuz yargılar içermektedir (Dyches vd., 2018; Kaymaz, 2017). Özellikle olumsuz nitelikte bulunan kitaplarda farklııklar ve zayıflıkları vurgulayan bir dil kullanımı gözlenmiş ve özel gereksinimli karakterleri mağdur ya da suçlu olarak betimleyecek davranış ve tutumlara yer verilmiştir. Bu kapsamda kişisel tasvirler açısından çocuk kitaplarında özel gereksinimli bireyleri etiketleyen ifadelerden kaçınılması ve karakterlerin gelişmiş özellikleri ile diğer bireylerle benzerliklerinin vurgulanması önerilebilir.

Sosyal etkileşimler açısından alan yazına paralel olan bulgular, kitaplarda özel gereksinimli karakterlerin çoğunlukla kabul edilen ve saygı duyulan bireyler olarak betimlendiğini göstermektedir (Dyches, Prater ve Leininger, 2009). Ancak bu karakterlerin başkalarının gelişimini desteklemesi yani olumlu sosyal katkıları ve çoklu ilişkiler içinde olması daha az sıklıkta rastlanan özelliklerdir. Bu bulguya benzer şekilde Dyches ve diğerleri (2018) çocuk kitaplarında özel gereksinimli karakterlerin olumlu sosyal etkileşimler içinde olsa da daha durağan rollerde betimlendiğini bildirmişlerdir. $\mathrm{Az}$ sayıda kitapta da özel gereksinimli karakterlerin yalıtılmış ortamlarda ve sınırlı sosyal ilişkiler içinde gösterildiği ve zaman zaman da akranları tarafından alay edildiği veya kardeşleri tarafından azarlandığı görülmüştür. Özel gereksinimli karakterlerin çocuk kitaplarında hem akranları hem de diğer bireylerle olumlu katkı sağlayıcı etkileşimlerine daha fazla yer verilmesi özel gereksinimli bireylerin günlük yaşamda daha fazla kabul görmelerini destekleyebilir. Sosyal etkileşimler açısından özel gereksinimli karakterlerin aile üyeleri ile ilişkileri de öne çıkan bulgular arasındadır. Değerlendirilen kitaplarda alan yazına paralel olarak baba ve kardeş gibi karakterlere anne karakterinden daha az rastlanmış olup (Kangal, Karaaslan ve Arslan, 2018) özel gereksinimli karakterlerin aile üyeleri ile ilişkileri de farklı işlenmiştir. Özel gereksinimli karakterle ilgilenen kişi çoğunlukla anne olup özel gereksinimli karakterin kardeş ve babaları ile etkileşimleri daha sınırlıdır. Bu durum özel gereksinimli bireylerin aile içi ilişkilerine dair kısıtı bir bakış açısı sunduğundan özel gereksinimli karakter içeren çocuk kitapları kardeş ve baba ilişkileri yönünden zenginleştirilebilir.

Mevcut çalışma kapsamında özel gereksinimli karakterlerin deneyimlediği örnek uygulamalar açısından çocuk kitaplarında niteliğin artırılmasına ihtiyaç duyulduğu sonucuna ulaşılmıştır. Bu bulgu özel gereksinimli olan karakterlerin eşit fırsatlara sahip olduğuna ve gerçekçi bir biçimde tanımlandığına işaret eden geçmiş araştırmalarla çelişmektedir (Dyches, Prater ve Cramer, 2001). Özel gereksinimli bireylere sunulan hizmetlerin yaygınlaşması ve toplumsal farkındalığın artması ile çocuk kitaplarında örnek uygulamalar alanında gelişmeler kaydedilebilir. Değerlendirilen kitapların büyük bir çoğunluğunun örnek uygulamalar boyutunda ya kabul edilebilir ya da olumsuz nitelikte olduğu görülmüştür. Bu kitaplarda yer verilen okul, hastane, park gibi ortamların genel çeşitliliği özel gereksinimli karakterlerin deneyimlediği örnek uygulamalar açısından önemli olmakla birlikte 
olumsuz ve bazı kabul edilebilir nitelikteki kitaplarda özel gereksinimli karakterlerin ev ortamındaki deneyimleri vurgulanmıştır. Bu açıdan çocuk kitaplarında özel gereksinimli karakterlerin farklı toplumsal fırsatlardan yararlanmasına yeterince yer verilmediği ifade edilebilir. Özel gereksinimli karakterlerin toplumsal kaynakları kullanma, seçimler yapma ve uygun hizmetlerden yararlanma gibi deneyimlerine olumlu nitelendirilen az sayıda kitapta yer verilmiş olması bu konuda gelişmeye duyulan intiyacı ortaya koymaktadır. Özellikle, yeni yazılacak çocuk kitaplarında özel gereksinimli bireylerin yaş, ilgi ve becerilerine uygun hizmetlerden faydalandıkları ve meslek edinme ve istihdam süreçlerine dair örneklere yer verilmesinin okul öncesi dönemde farkındalık geliştirmeye katkı sağlayacağı ifade edilebilir.

Bu çalışma ile özel gereksinimli bireylere yönelik farkındalık geliştirme konusunda okul öncesi öğretmenlerinin başvurabileceği çocuk kitapları belirlenmiştir. Bu kitapların bazılarının drama ile desteklenerek kullanıldığı bir çalışmada okul öncesi dönem çocuklarının özel gereksinimli bireylere yönelik farkındalıklarının arttığı ve işitme, zihin ve ortopedik yetersizlikler hakkında bilgilendikleri gözlenmiştir (Erdoğan ve Baş, 2018). Böylesine önemli bir konuda farkındalık geliştirmek için öğretmenlerin daha fazla kaynağa ihtiyaçları olduğu ve sınıf içinde çalışmalarını çeşitlendirmeleri gerektiği de dikkate alınmalıdır. Bu bağlamda, kitap satışı yapan internet sitelerinde çocuk kitapları bölümlerinin tematik başlıklarla ayrılması öğretmenlerin benzer kitaplara ulaşmalarını kolaylaştıracaktır. Kütüphanelerde de çocuk kitapları için özel bölümlerin olması ve bu bölümlerde kitapların farklı yaş gruplarını ayırabilecek şekilde yerleştirilmesi bu kitaplara erişimi artıracaktır. Diğer taraftan, önerilen bu kitapların sadece sınıfa özel gereksinimli bir öğrenci gelmeden önce okunması (Ağgül-Yalçın ve Yalçın, 2018) yeterli olmayıp özel gereksinimli bireylere yönelik farkındalık geliştirmek ve olumlu tutumları desteklemek için bu çalışmaları zamana yaymak ve çocuklara kitapların içeriği ile ilgili yansıtıcı sorular sormak önemlidir. Yansıtıcı sorular konusunda Price, Ostrosky ve Santos (2016) kitaplara konu olan özel gereksinimli karakterlerin sorun çözme konusunda etkin olup olmadığının, hikâyedeki rollerinin ve diğer karakterlerle sosyal ilişkilerinin değerlendirilmesini önermektedirler. Ayrıca, okunacak bu kitapların farklı etkinliklerle desteklenmesi çocukların özel gereksinimli bireylere yönelik olumlu tutumlar geliştirmelerine katkı sağlayacaktır (Ostrosky vd., 2015).

Bu çalışmanın bazı sınırıııkları kapsamında çeşitli öneriler sunulabilir. Okul öncesi öğretmenlerinin özel gereksinimli bireylere yönelik farkındalık geliştirmede kullanabileceği kitapları belirlemek bu araştırmanın temel amaçlarından biri olduğu için örneklemede belli yıl aralıkları kullanılmamış ve öğretmenlerin kolay erişebileceği İnternet sitelerinde tarama yapılmıştır. Ayrıca, öğretmenlerin erişemeyeceği düşünüldüğünden basımı sonlandırılmış kitaplar çalışmaya dâhil edilmemiştir. Bazı kitapların ise hangi yetersizlik grubunda olacağına karar verirken, yeterli bilgi verilmeyen durumlarda ilgili kitap en yakın görünen yetersizlik grubuna dâhil edilmiştir. Örneğin, Aleks çok Hassas isimli kitapta geçen "Sakın unutma anne! Bu akşam piknik var. İşten çıkar çıkmaz babamla hemen okula gelin" gibi ifadeler OSB için tipik iletişim örnekleri değildir. Bu konudaki araştırmalarda da OSB'nin temel özellikleri arasında iletişim problemleri gösterilmekte ve sözel ve sözel olmayan iletişim becerilerinin tipik gelişimden farklı yönleri vurgulanmaktadır (Ökcün-Akçamuş, 2016). Ancak Aleks'in OSB için tipik olan duyusal uyaranlara karşı hassasiyeti vurgulandığı için bu kitap çalışmada OSB grubuna dâhil edilmiştir. Diğer taraftan Dayni ve Hiperaktif Ayı isimli kitapta "hiperaktif" sözcüğü bir yavru ayının uyuyamamasını betimlediği için bu kitap da sadece pilot uygulama için kullanılmıştır. Gelecek araştırmalarda kütüphane katalogları kullanılarak değerlendirilen kitapların sayısı çoğaltılabilir. İnternet taraması ile ulaşılan eserlerin çoğunun tercüme olduğu da dikkate alındığında ileriki yıllarda sayısı artacağı düşünülen Türkçe eserlerle yeni araştırmalar yapılabilir. Ayrıca, çocuk kitaplarında özel gereksinimli bireyleri tanımlayan farklı kavramlar kullanıldığı için dil birliğine gidilmesi yönünde Türk Dil Kurumu ve özel eğitim uzmanları işbirliği yapabilirler. TÜik, MEB ve Sağlık Bakanlığı gibi kurumların sınıflandırmalarında da uluslararası standartların temel alınması akademik yazında da dil birliğine ulaşmaya katkı sağlayacaktır.

Bu araştırmada hem bilimsel çalışmalarda hem de Dolly Gray Çocuk Edebiyatı Ödülleri için çocuk ve gençlik kitaplarının değerlendirilmesinde kullanılan bir araç kullanılmıştır (Dyches vd., 2018). $\mathrm{Bu}$ araç kapsayıcı eğitim felsefisine temel oluşturacak farklı boyutlar içerdiği için tercih edilmiştir. 
Ancak bu aracın kullanımında belli bir olay örgüsü içeren öykü kitaplarına başvurulmakta ve özel gereksinimli karakterlerin hayvan olarak alındığı kitaplar önerilmemektedir. Özel gereksinimli bireyler konusunda Türkiye'deki çocuk kitabı sayısı yurtdışına nazaran oldukça düşük olduğundan ve okul öncesi dönem çocuk kitaplarında hayvan karakterler yaygın kullanıldığından bu çalışmada hayvan karakter içeren üç kitap değerlendirme kapsamına alınmıştır. Yeni araştırmalarda farklı yaş gruplarını da içerecek şekilde özel gereksinimli karakterlerin sadece insan olduğu çocuk kitapları kullanılabilir. Özel gereksinimli karakterler içeren nitelikli çocuk kitaplarının sınırlı sayıda olmasından hareketle bu konuda okul öncesi çocuk kitabı setleri hazırlanması önerilebilir. Bu setlere dâhil edilecek kitaplarda farklı yetersizlik gruplarında ve farklı yaşlarda özel gereksinimli karakterlere özellikle yan karakter olarak yer verilerek akıcı hikâyelerle özel gereksinimli bireylerin güçlü yönleri, çeşitli ortamlardaki etkileşimleri ve topluma katkıları betimlenebilir. Bu noktada Türkiye'deki çocuk kitabı yazarları, çocuk gelişimi uzmanları, okul öncesi eğitimciler, özel eğitim uzmanları, görsel sanatlar uzmanları ve grafikçiler okul öncesi yaşlarda çocuklarla da işbirliği yaparak bu alanda gözlenen ihtiyaca cevap verebilirler.

\section{Yazarların Katkı Oranı}

1. yazar $\% 25$, 2. yazar $\% 25$, 3. Yazar $\% 25$, 4. Yazar $\% 25$ oranlarında olmak üzere tüm yazarlar bu çalışmaya eşit katkı sağlamışlardır.

\section{Çıkar Çatışması}

Çıkar çatışması teşkil edebilecek bir durum yoktur.

\section{Kaynaklar}

Ackah-Jnr, F. R. (2020). Inclusive education, a best practice, policy and provision in education systems and schools: The rationale and critique. European Journal of Education Studies, 6(10), 171183. doi: $10.5281 /$ zenodo. 360512

Ağgül-Yalçın, F. ve Yalçın, M. (2018). Okul öncesi öğretmenlerin okul öncesi eğitimin sorunlarıyla ilgili görüşleri: Ağrı ili örneği. Elementary Education Online, 17(1), 367-383. Doi 10.17051/ilkonline.2018.413784

Armstrong, A. C. Armstrong, D. ve Spandagou, I. (2010). Inclusive education: International policy \& practice. London: SAGE Publications Ltd.

Bakkaloğlu, H. Sucuoğlu, B. ve Özbek, A. B. (2019). Okul öncesinde özel gereksinimli olan ve normal gelişen çocukların sosyal kabul düzeylerinin incelenmesi. Ilköğretim Online, 18(2), 521-538. doi:10.17051/ilkonline.2019.562011

Boer, A., Pijl, S. J., Post, W. ve Minnaert, A. (2013). Peer acceptance and friendships of students with disabilities in general education: The role of child, peer, and classroom variables. Social Development, 22(4), 831-844. doi: 10.1111/j.1467-9507.2012.00670.x

Bricker, D. (1995). The challenge of inclusion. Journal of early intervention, 19(3), 179-194. https://doi.org/10.1177/105381519501900301

Burke, K. ve Sutherland, C. (2004). Attitudes toward inclusion: Knowledge vs. experience. Education, 125(2), 163-172.

Buysse, V., Wesley, P. W., Bryant, D. ve Gardner, D. (1999). Quality of early childhood programs in inclusive and noninclusive settings. Exceptional Children, 65(3), 301-314.

Büyüköztürk, Ş., Çakmak-Kılıç, E., Erkan-Akgün, Ö., Karadeniz, Ş. ve Demirel, F. (2012). Eğitimde bilimsel araştırma yöntemleri. Ankara: Pegem Akademi.

Cross, A. F., Traub, E. K., Hutter-Pishgahi, L. ve Shelton, G. (2004). Elements of successful inclusion for children with significant disabilities. Topics in Early Childhood Special Education, 24(3), 169183.

Çiftçi, F. (2013). Çocuk edebiyatında yaş gruplarına göre kitaplar ve özellikleri. Anemon Muş Alparslan Üniversitesi Sosyal Bilimler Dergisi, 1(1), 125-137. 
Diamond, K. E. ve Hestenes, L. L. (1996). Preschool children's conceptions of disabilities: The salience of disability in children's ideas about others. Topics in Early Childhood Special Education, 16(4), 458-475. doi:10.1.1.839.5806\&rep=rep1\&type=pdf

Dirican, R. ve Dağlıoğlu, H. E. (2014). 3-6 Yaş grubu çocuklarına yönelik yayımlanan resimli hikâye kitaplarının bazı temel değerler açısından incelenmesi. Cumhuriyet International Journal of Education, 3(2), 44-69.

Doğaroğlu, T. ve Dümenci, S. B. (2015). Sınıflarında kaynaştırma öğrencisi bulunan okul öncesi öğretmenlerin kaynaştırma eğitimi ve erken müdahale hakkındaki görüşlerinin incelenmesi. Hacettepe Üniversitesi Sağlık Bilimleri Fakültesi Dergisi, 1(2), 460-473.

Dyches, T. T. ve Prater, M. (2000). Developmental disability in children's literature: Issues and annotated bibliography. Reston, VA: Council for Exceptional Children/Mental Retardation and Developmental Disabilities (78 pages; work solicited by CEC/MRDD for inclusion in the "Prism" series of monographs).

Dyches, T. T. ve Prater, M. A. (2005). Characterization of developmental disability in children's fiction. Education and Training in Developmental Disabilities, 40(3), 202-216.

Dyches, T. T., Egan, K., Moss, K., Grow, H., Black, S. ve Prater, M. A. (2018). Same but different: Characters with developmental disabilities in current juvenile literature. DADD Online Journal: Research to Practice, 5(1), 73-89. https://scholarsarchive.byu.edu/facpub/2978 adresinden edinilmiştir (Erişim tarihi: 28.10.2019).

Dyches, T. T., Prater, M. A. ve Cramer, S. F. (2001). Characterization of mental retardation and autism in children's books. Education and Training in Mental Retardation and Developmental Disabilities, 36(3), 230-243.

Dyches, T. T., Prater, M. A. ve Leininger, M. (2009). Juvenile literature and the portrayal of developmental disabilities. Education and Training in Developmental Disabilities, 44(3), 304317.

Eğitim Reformu Girişimi (ERG) (2016). Türkiye'de kapsayıcı eğitimi yaygınlaştırmak için politika önerileri.

http://www.egitimreformugirisimi.org/wpcontent/uploads/2017/03/ERG_KapsayiciEgitim_P olitika_Onerileri.pdf adresinden edinilmiştir (Erişim tarihi: 28.10.2019).

Erdoğan, F. K. ve Baş, S. (2018). Özel gereksinimli birey farkındalığııın 4-6 yaş çocuklarına kazandırıması. Yaratıcı Drama Dergisi, 13(1). 101-114. doi:https://doi.org/10.21612/yader.2018.007

Eratay, E. ve Sazak-Pınar, E. (2006). Genel eğitim sınıflarındaki zihinsel engelli öğrencilerin arkadaşlık ilişkilerinin incelenmesi. Abant İzzet Baysal Üniversitesi Sosyal Bilimler Enstitüsü Dergisi, 13(2), 24- 47.

Favazza, P. C., LaRoe, J., Phillipsen, L. ve Kumar, P. (2000). Representing young children with disabilities in classroom environments. Young Exceptional Children, 3(3), 2-8.

Favazza, P. C., Ostrosky, M., \& Mouzourou, C. (2016). The making friends program: Supporting acceptance in your K-2 classroom. Baltimore: Brookes Publishing.

Gönen, M., Dursun, A., Topcu-Bilir, Z., Tarman, I. ve Nur, I. (2015). A study on the depiction of disability in illustrated story books. Revista de Cercetare si Interventie Sociala, 50, 275-292.

Gök, G. ve Erbaş, D. (2011). Okulöncesi eğitimi öğretmenlerinin kaynaştırma eğitimine ilişkin görüşleri ve önerileri. International Journal of Early Childhood Special Education, 3(1), 66-87.

Güzelyurt, T. ve Saraç, S. (2018). 48-66 Aylık çocukların gelişim düzeylerine uygun çocuk kitapları nasıl olmalıdır? Bir Delphi çalışması. Uluslararası Çocuk Edebiyatı ve Eğitim Araştırmaları Dergisi (ÇEDAR), 2(1), 52-75.

Işıtan, S. (2016). Özel amaçla yazılmış çocuk kitapları. Journal of Turkish Studies, 11(4), 471-.492. doi: https://doi.org/10.7827/TurkishStudies.9086

Kangal, S. B., Karaaslan, A. ve Arslan, S. (2018). Okul öncesi dönem resimli çocuk kitaplarında yer alan baba figürünün incelenmesi. Ulus/ararası Çocuk Edebiyatı ve Eğitim Araştırmaları Dergisi (ÇEDAR), 2(2), 18-31.

Karasar, N. (2013). Bilimsel araştırma yöntemi. (25. Basım), Ankara: Nobel Akademik Yayıncılık. 
Karataş, E. (2014). Çocuk edebiyatında "karakter" kavramı. Sosyal ve Beşeri Bilimler Araştırmaları Dergisi, 33, 60-79.

Karadağ, F., Yıldız-Demirtaş, V. ve Girli, A. (2014). Okul öncesi dönemde akranların sınıflarındaki özel gereksinimli öğrenciyi tercih etme durumları. Mehmet Akif Ersoy Üniversitesi Eğitim Fakültesi Dergisi, 1(31), 191-215.

Karatay, H. (2011). Çocuk edebiyatı metinlerinde bulunması gereken özellikler. T. Şimşek (Ed), Kuramdan uygulamaya çocuk edebiyatı el kitabı. (s.77-123). Ankara: Grafiker Yayınları.

Kaymaz, Ç. (2017). Özel gereksinimliliği içeren Türkçe ve çeviri resimli çocuk kitaplarının incelenmesi. Yayınlanmamış yüksek lisans tezi. Ankara, Hacettepe Üniversitesi, Sağlık Bilimleri Enstitüsü. Yükseköğretim Kurulu Ulusal Tez Merkezinden edinilmiştir. (Tez Numarası: 468855)

Kırkgöz, S. ve Diken, İ. H. (2019). Özel gereksinimli kahramanı bulunan resimli çocuk kitaplarının incelenmesi. Erken Çocukluk Çalışmaları Dergisi, 3(2), 493-513. doi: 10.24130/eccdjecs.1967201932175

Koçyiğit, S. (2015). Ana sınıflarında kaynaştırma eğitimi uygulamalarına ilişkin öğretmen-rehber öğretmen ve ebeveyn görüşleri. Uluslararası Türkçe Edebiyat Kültür Eğitim Dergisi, 4(1), 391415.

Leininger, M., Dyches, T. T., Prater, M. A. ve Heath, M. A. (2010). Newbery award winning books 1975-2009: How do they portray disabilities? Education and Training in Autism and Developmental Disabilities, 45(4), 583-596.

MEB (1997). Özel Eğitim Hakkında Kanun Hükmünde Kararname.https://orgm.meb.gov.tr/meb_iys_dosyalar/2012_10/10111011_ozel_egitim_kan un_hukmunda_kararnme.pdf adresinden edinilmiştir (Erişim tarihi: 09.11.2019).

MEB (2013). Okul öncesi eğitim programı. https://tegm.meb.gov.tr/dosya/okuloncesi/ooproram.pdf adresinden edinilmiştir (Erişim tarihi: 30.02 .2020 ).

MEB (2018a). Kapsayıcı eğitim projesi. https://oygm.meb.gov.tr/www/kapsayici-egitim-projesiinclusive adresinden edinilmiştir (Erişim tarihi:28.10.2019).

MEB (2018b). Özel Hizmetleri Yöitim https://orgm.meb.gov.tr/meb_iys_dosyalar/2018_07/09101900_ozel_egitim_hizmetleri_yon etmeligi_07 adresinden edinilmiştir (Erişim tarihi: 16.06.2019).

MEB (2018c). Milli eğitim istatistikleri: Örgün eğitim. http://sgb.meb.gov.tr/www/icerik_goruntule.php?KNO=361 adresinden edinilmiştir (Erişim tarihi: 16.06.2019).

Mert, O., Albayrak, F. ve Serin, N. (2013). Çeviri çocuk kitaplarının kültür aktarımı açısından incelenmesi. Ana Dili Eğitimi Dergisi, 1(3), 58-73.

Metin, N., Şenol, B. ve Yumuş, M. (2015). Okul öncesi eğitim sınıflarına kaynaştırılan otistik çocukların sosyometrik statülerinin incelenmesi. Hacettepe Üniversitesi Sağlık Bilimleri Fakültesi Dergisi, 1(2), 483-490.

Miles, M. B. ve Huberman, A. M. (2015). Nitel veri analizi: genişletilmiş bir kaynak kitap (1. Baskı). S. Akbaba Altun ve A. Ersoy (Çev. Eds). Ankara: Pegem Akademi.

Mncube, V. S. ve Lebopa, N. (2019). The dynamics of implementing inclusive education in schools. Global Education in Practice: Teaching, Researching, and Citizenship, 17, 146-152. Doi: 978619-7326-08-6

Nelson, A. ve Nelson, V. (2016). "Other" characters: The gendering and racialization of "disability" within Newbery award-winning books. Canadian Journal of Family and Youth, 8(1), 73-101.

Odom, S. L., Buysse, V. ve Soukakou, E. (2011). Inclusion for young children with disabilities: A quarter century of research perspectives. Journal of Early Intervention, 33(4), 344-356. https://doi.org/10.1177/1053815111430094

Odom, S. L., Zercher, C., Li, S., Marquart, J. M., Sandall, S. ve Brown, W. H. (2006). Social acceptance and rejection of preschool children with disabilities: A mixed method analysis. Journal of Educational Psychology, 98(4), 807-823. https://doi.org/10.1037/0022-0663.98.4.807 
Ostrosky, M. M., Mouzourou, C., Dorsey, E. A., Favazza, P. C. ve Leboeuf, L. M. (2015). Pick a book, any book: Using children's books to support positive attitudes toward peers with disabilities. Young Exceptional Children, 18(1), 30-43. https://doi.org/10.1177/1096250613512666

Ökcün-Akçamuş, M. Ç. (2016). Otizm spektrum bozukluğu olan çocukların sosyal iletişim becerileri ve dil gelişim özellikleri. Ankara Üniversitesi Eğitim Bilimleri Fakültesi Özel Eğitim Dergisi, 17(02), 163-192.

Özaydın, L. ve Çolak, A. (2011). Okul öncesi öğretmenlerinin kaynaştırma eğitimine ve okul öncesi eğitimde kaynaştırma eğitimi hizmet içi eğitim programına ilişkin görüşleri. Kalem Eğitim ve insan Bilimleri Dergisi, 1(1), 189-226.

Pamuk, D. K. ve Mazhar, B. A. L. (2019). Okul öncesi öğretmenlerinin kapsayıcı eğitimde çocukların dil gelişim sürecine yönelik görüşlerinin belirlenmesi. Milli Eğitim Dergisi, 48(1), 737-754.

Peck, C. A., Carlson, P. S., Helmstetter, E. (1992). Parent and teacher perceptions of outcomes for nonhandicapped children enrolled in integrated early childhood programs: A statewide study. Journal of Early Intervention, 16, 53-63.

Prater, M. A., Dyches, T. T. ve Johnstun, M. (2006). Teaching students about learning disabilities through children's literature. Intervention in School and Clinic, 42(1), 14-24. https://doi.org/10.1177/105381519201600105

Price, C. L., Ostrosky, M. M. ve Mouzourou, C. (2016). Exploring representations of characters with disabilities in library books. Early Childhood Education Journal, 44(6), 563-572. doi:10.1007/s10643-015-0740-3

Price, C. L., Ostrosky, M. M. ve Santos, R. M. (2016). Reflecting on books that include characters with disabilities. YC Young Children, 71(2), 30-37.

Rahayu, W. F. ve Kurniawati, F. (2019). The influence of teacher self-efficacy in teaching towards teacher attitude in inclusive preschool. Advances in Social Science, Education and Humanities Research, 388, 101-106. https://doi.org/creativecommons.org/licenses/by-nc/4.0

Sever, S. (2013). Çocuk edebiyatı ve okuma kültürü. İzmir: Tudem.

Sevim, O. (2020). Çocuk edebiyatıyla ilgili lisansüstü çalışmalardaki eğilimler: Bir içerik analizi. Türkiye Eğitim Dergisi, 5(1), 124-144.

Siagian, P. E. ve Kurniawati, F. (2019). Inclusive preschool teachers: their attitude and engagement toward inclusive education. Advances in Social Science, Education and Humanities Research, 388, 117-121. https://doi.org/creativecommons.org/licenses/by-nc/5.0

Smith, T. E. C., Polloway, E. A., Patton, J. R. ve Dowdy, C. A. (2012). Teaching students with special needs in inclusive settings (6th ed.). Boston: Pearson Education Inc.

Smith-D'Arezzo, W. M. ve Moore-Thomas, C. (2010). Children's perceptions of peers with disabilities. Teaching Exceptional Children Plus, 6(3), 1-16.

Stojik, T. (2009). A guide for advancing inclusive education practice. Belgrade: Dosije Studio.

Şahin, G. (2014). Okulöncesi dönem çocuk kitaplarında görsel bir uyaran olarak resim. Journal of Turkish Studies, 9(3), 1309-1324. Doi:https://doi.org/10.7827/TurkishStudies.6507

Turan, F. ve Ulutaş, í. (2016). Okul öncesi eğitim kurumlarındaki resimli öykü kitaplarının özellikleri ile öğretmenlerin bu kitapları kullanma durumlarının incelenmesi. Hacettepe Üniversitesi Eğitim Bilimleri Enstitüsü Eğitim Araştırmaları Dergisi, 2(1). 21-46.

Türkiye İstatistik Kurumu (TÜiK) (2010). Engellilerin sorun ve beklentileri araştırması. http://www.tuik.gov.tr/VeriBilgi.do?alt_id=1017 adresinden edinilmiştir (Erişim tarihi: 03.02.2020).

Ulutaş, B. (2015). Doküman analizi. F. N Seggie ve Y. Bayyurt (Ed), Nitel araştırma: Yöntem, teknik ve analiz yaklaşımları. (s.279-297). Ankara: Anı Yayıncılık.

UNESCO (1994) The Salamanca statement and framework for action on special needs education. Paris: UNESCO.

UNESCO (2017). A guide for ensuring inclusion and equity in education. Paris: UNESCO.

Wolfberg, P. J., Zercher, C., Lieber, J., Capell, K., Matias, S., Hanson, M. ve Odom, S. L. (1999). "Can I play with you?" Peer culture in inclusive preschool programs. Journal of the Association for Persons with Severe Handicaps, 24, 75-81. 
Woodgate, R. L., Gonzalez, M., Demczuk, L., Snow, W. M., Barriage, S. ve Kirk, S. (2019). How do peers promote social inclusion of children with disabilities? A mixed-methods systematic $\begin{array}{llll}\text { review. Disability } & \text { 1-27. }\end{array}$ https://doi.org/10.1080/09638288.2018.1561955

Vuran, S. (2014). Stories about children with disabilities: The writing process and the opinions of the storywriters. Eurasian Journal of Educational Research. (55), 137-158. doi:https://doi.org/10.14689/ejer.2014.55.9

Yakar, Y. M., Yılmaz, O., \& Yılmaz, H. D. (2019). Çocuk kitaplarında sorun odaklılık: engellilik algısı. Avrasya Dil Eğitimi ve Araştırmaları Dergisi, 3(1), 56-76.

Yıldırım, A. ve Şimşek, H. (2011). Sosyal bilimlerde nitel araştırma yöntemleri. Ankara: Seçkin Yayınları.

Yıldız, C., Yazıcı, D. N. ve Durmuşoğlu, M. C. (2016). 2010-2015 Yılları arasında yayımlanmış resimli çocuk kitaplarının resimleme özelliklerinin incelenmesi. Uluslararası Erken Çocukluk Eğitimi Çalışmaları Dergisi, 1(1). 43-55.

Yıldız, Ç. M. ve Arıkan, A. (2019). Okul öncesi çocuklarında özel gereksinimli bireylere yönelik farkındalık geliştirilmesi konusunda öğretmenlerin görüşleri. 6. Uluslararası Okul Öncesi Eğitimi Kongresi. Kars: Kafkas Üniversitesi Eğitim Fakültesi, ss. 759-761.

Yükselen, A., Yumuş, M. ve Işık, E. (2016). Çocuk kitabı seçme kriterlerine ilişkin okul öncesi eğitimcilerin görüşleri. Başkent University Journal of Education, 3(2), 161-168.

\section{Introduction}

\section{Extended Abstract}

One of the main goals of inclusive education is to develop awareness about individuals with special needs starting from preschool ages. Several legal regulations and practices are implemented in many countries to ensure inclusive education that benefits all children. Still, the literature points to various problems faced by individuals with special needs, the families, and the teachers in the education system. Some of these problems relate to teachers not having enough knowledge, positive attitudes, resources, and support for the education of individuals with special needs and schools' physical conditions. Besides, preschool children with special needs encounter problems in being accepted, included, and feeling valuable in inclusive settings. These problems reveal the need to raise awareness about individuals with special needs starting from the early years. Indeed, studies emphasize the importance of changing the perspectives and attitudes of typically developing children. At this point, children's literature is one of the most frequently used tools in raising awareness about individuals with special needs. Several studies suggest using children's books to promote positive attitudes towards individuals with special needs among typically developing children. Based on such context, this study describes the quality of preschool children's books containing characters with special needs and identifies quality resources available to teachers in Turkey.

\section{Method}

This descriptive study used document analysis as a research approach, and preschool children's books served as the primary data source. Convenient sampling and criterion sampling methods were used to determine the books. Maintaining ease of access for teachers was the primary concern; therefore, an online search was conducted in three bookstores. The search resulted in 58 books, and 20 of these books met the study's age, content, and accessibility criteria. The books were evaluated using an international tool developed for the Dolly Gray Children's Literature Award. This Likert-type scale consists of eight sub-sections: overall reaction, personal portrayal, social interactions, exemplary practices, sibling relationships, point of view, the literary quality of text and illustrations. The study team evaluated the books using this tool and discussed the ratings to reach a consensus on the scores. The inter-rater reliability score was calculated, indicating a $90 \%$ consistency between the raters' evaluations. 


\section{Result and Discussion}

This study described the qualities of children's books containing characters with special needs in a multidimensional way. They suggest that preschool teachers can use books with positive or neutral quality ratings to raise awareness about individuals with special needs. In positively rated books (12), characters with special needs had access to equal rights like others, had high social participation, and were accepted by their family and social environment. The books with negative quality ratings (4) included exclusion, labeling, and social isolation and descriptions of the special needs characters as perpetrators or victims. The books with neutral quality (4) included generally positive content, but such features as using inappropriate words, focusing on differences, and characters' static roles in social life were also visible. There were only six books with positive quality ratings in all dimensions (personal portrayal, social interactions, and exemplary practices). The majority of the books were translations from foreign languages, and only four were initially written in Turkish. The findings of the study corroborate with previous studies. In general, some disability groups such as language and speech disorders were underrepresented in children's books. The gender distributions for characters with special needs were also disproportionate, favoring male characters. The vast majority of the characters were school-age children, and most of them were the main characters. The study suggests that portraying special needs characters from varying ages as supporting characters in children's books may promote positive attitudes among typically developing children via non-didactic ways. As for the dimensions of the quality representations, personal portrayals of special needs characters were generally positive. Still, there is a need to emphasize the characters' advanced features and their similarities to other individuals. Social interactions also depicted the characters with special needs as accepted and respected individuals, but the characters' multiple relationships and social contributions were less common. Children's books containing characters with special needs can also be enriched in sibling and father relationships. Finally, the quality of children's books in terms of exemplary practices should be improved. The majority of the books were either rated as neutral or negative quality in exemplary practices dimension. The experiences of characters with special needs in using social resources, making choices, and benefiting from appropriate services are included in only a few books. Future studies may use library catalogs and focus on books to be written by Turkish authors. Since different concepts are used to define individuals with special needs in children's books and elsewhere, the Turkish Language Institute and special education professionals can cooperate to identify shared concepts and reach uniformity in descriptions. 


\section{Ek-1. Örnekleme Aşamasında Ulaşılan Kitaplar*}

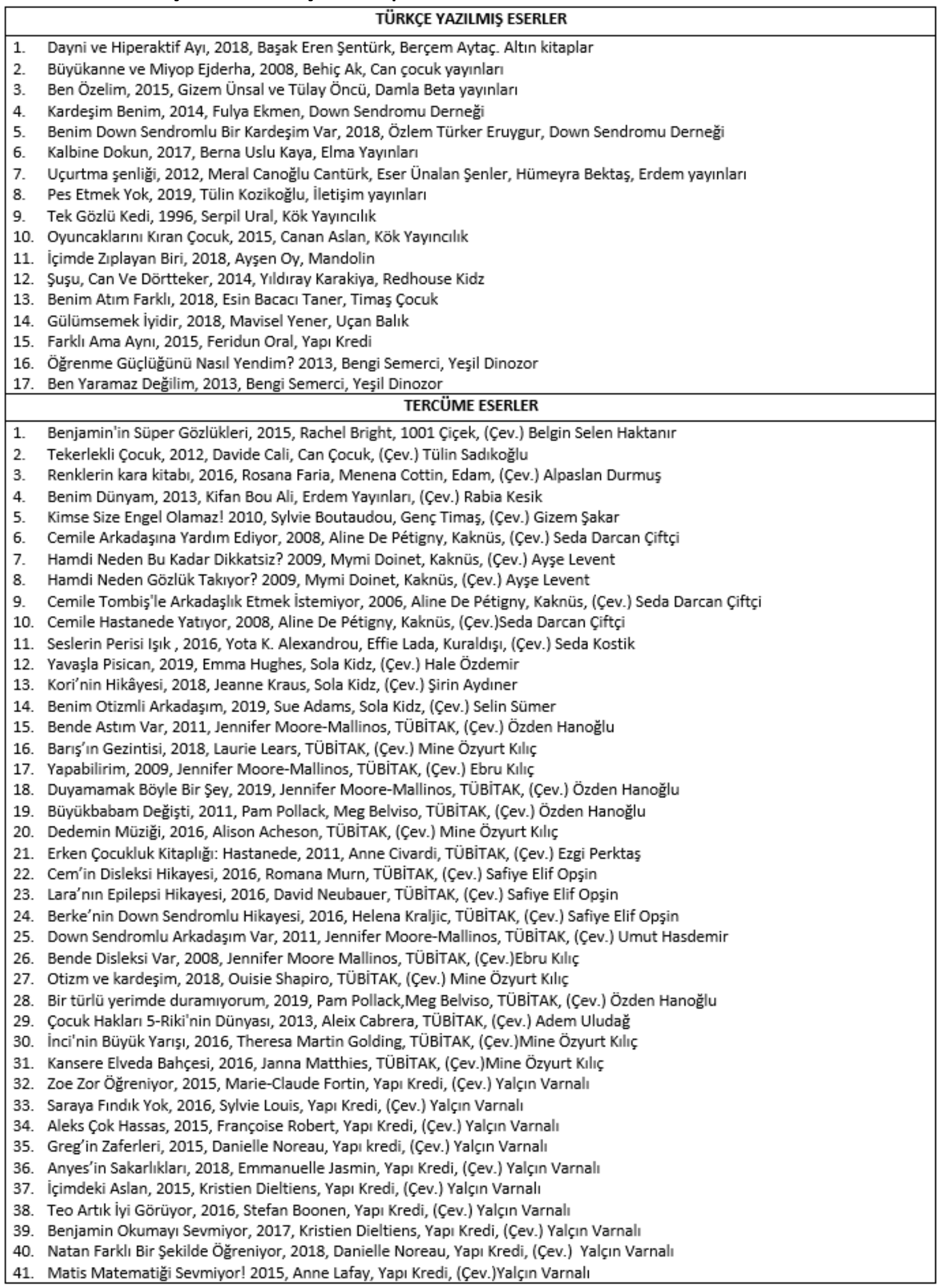

*Liste yayınevi adlarına göre alfabetik sırada hazırlanmıştır 
Ek-2. Pilot Uygulamada Kullanılan Kitaplar

\begin{tabular}{|l|c|l|l|l|}
\hline Kitap İsmi & $\begin{array}{c}\text { Yayın } \\
\text { Yılı }\end{array}$ & Yazar & Çevirmen & Yayınevi \\
\hline Renklerin kara kitabı & 2016 & Rosana Faria, Menena Cottin & Alpaslan Durmuş & Edam \\
\hline Erken Çocukluk Kitaplığı: Hastanede & 2011 & Anne Civardi & Ezgi Perktaş & Tübitak \\
\hline Teo Artık Iyi Görüyor & 2016 & Stefan Boonen & Yalçın Varnalı & Yapı Kredi \\
\hline Benjamin Okumayı Sevmiyor & 2017 & Kristien Dieltiens & Yalçı Varnalı & Yapı Kredi \\
\hline Hamdi Neden Gözlük Takıyor? & 2009 & Mymi Doinet & Ayşe Levent & Kaknüs \\
\hline $\begin{array}{l}\text { Cemile Tombiş'le Arkadaşlık Etmek } \\
\text { İstemiyor }\end{array}$ & 2006 & Aline De Pétigny & Seda Darcan Çiftçi & Kaknüs \\
\hline Cemile Hastanede Yatıyor & 2008 & Aline De Pétigny & Seda Darcan Çiftçi & Kaknüs \\
\hline Tek Gözlü Kedi & 1996 & Serpil Ural & & Kök \\
\hline Dayni ve Hiperaktif Ayı & 2018 & $\begin{array}{l}\text { Başak Eren Şentürk, } \\
\text { Berçem Aytaç }\end{array}$ & Altın kitaplar \\
\hline
\end{tabular}

Ek-3. Değerlendirilen Kitapların Alt Başılıklarda Aldıkları Puanlar

\begin{tabular}{|c|c|c|c|c|c|c|}
\hline Kitap Kodu & $\begin{array}{c}\text { Kișisel } \\
\text { Tasvirler }\end{array}$ & $\begin{array}{c}\text { Sosyal } \\
\text { Etkileşim }\end{array}$ & $\begin{array}{c}\text { Örnek } \\
\text { Uygulamalar }\end{array}$ & $\begin{array}{c}\text { Toplam } \\
\text { Puanlar }\end{array}$ & $\begin{array}{c}\text { Ortalama } \\
\text { Puan }\end{array}$ & Değerlendirme \\
\hline K1 & 2 & 2,4 & 1,4 & 5,80 & 1,93 & Olumsuz \\
\hline K2 & 4,5 & 4,6 & 3,8 & 12,9 & 4,3 & Olumlu \\
\hline K3 & 4 & 4,6 & 3,6 & 12,2 & 4,06 & Olumlu \\
\hline K4 & 4 & 3,8 & 3,6 & 11,4 & 3,80 & Olumlu \\
\hline K5 & 4 & 2,8 & 3,2 & 10 & 3,33 & Kabul Edilebilir \\
\hline K6 & 3,83 & 2,6 & 2 & 8,43 & 2,81 & Kabul Edilebilir \\
\hline K7 & 4,83 & 4,6 & 3,6 & 13,03 & 4,34 & Olumlu \\
\hline K8 & 5 & 4,8 & 3,6 & 13,40 & 4,46 & Olumlu \\
\hline K9 & 4,83 & 5 & 4 & 13,83 & 4.61 & Olumlu \\
\hline K10 & 5 & 5 & 4 & 14 & 4,66 & Olumlu \\
\hline K11 & 4,5 & 4,6 & 3,6 & 12,70 & 4.23 & Olumlu \\
\hline K12 & 5 & 4,8 & 4 & 13,80 & 4,6 & Olumlu \\
\hline K13 & 3,16 & 4,4 & 3,4 & 10,96 & 3,65 & Kabul Edilebilir \\
\hline K14 & 3 & 4,4 & 3,4 & 10,80 & 3,60 & Kabul Edilebilir \\
\hline K15 & 2 & 1,8 & 1,6 & 5,40 & 1,8 & Olumsuz \\
\hline K16 & 2 & 2,2 & 2,2 & 6,40 & 2,13 & Olumsuz \\
\hline K17 & 4,33 & 3,4 & 3,6 & 11,33 & 3,78 & Olumlu \\
\hline K18 & 1 & 1 & 1 & 3 & 1 & Olumsuz \\
\hline K19 & 4,66 & 4 & 4 & 13,66 & 4,55 & Olumlu \\
\hline K20 & 4,83 & 4,8 & 4 & 13,63 & 4,54 & Olumlu \\
\hline
\end{tabular}

Puanlama: Olumsuz=1-2.5; Kabul edilebilir=2.6-3.75; Olumlu=3.76-5.0 (Dyches vd. 2018).

\section{Ek-4. Araştırmacıların Uzlaştığı Değerlendirme Sonuçları}

\begin{tabular}{|l|l|l|l|l|l|l|l|l|l|l|l|l|l|l|l|l|l|l|l|l|}
\hline Kitap No $\rightarrow$ & $\mathbf{1}$ & $\mathbf{2}$ & $\mathbf{3}$ & $\mathbf{4}$ & $\mathbf{5}$ & $\mathbf{6}$ & $\mathbf{7}$ & $\mathbf{8}$ & $\mathbf{9}$ & $\mathbf{1 0}$ & $\mathbf{1 1}$ & $\mathbf{1 2}$ & $\mathbf{1 3}$ & $\mathbf{1 4}$ & $\mathbf{1 5}$ & $\mathbf{1 6}$ & $\mathbf{1 7}$ & 18 & 19 & 20 \\
\hline Genel Etki & E & A & N & N & N & N & A & A & A & A & A & A & N & N & E & E & N & E & A & A \\
\hline Kişisel Tasvirler & E & A & A & A & A & A & A & A & A & A & A & A & N & N & E & E & A & E & A & A \\
\hline Sosyal Etkilesimler & E & A & A & A & N & N & A & A & A & A & A & A & A & A & E & E & N & E & A & A \\
\hline Örnek Uygulamalar & E & A & N & N & N & E & N & N & A & A & N & A & N & N & E & E & N & E & A & A \\
\hline Kardes Iliskileri & E & Y & A & A & A & Y & Y & Y & Y & Y & Y & Y & Y & E & E & Y & Y & E & Y & Y \\
\hline Bakis Açlar & N & A & A & A & A & A & N & A & A & A & A & A & A & E & E & E & A & E & A & A \\
\hline Edebi Nitelik & N & A & A & A & A & N & A & A & A & A & A & N & A & N & E & E & N & E & A & A \\
\hline Resimleme & N & A & A & A & A & A & A & A & A & A & A & A & A & A & N & N & A & N & A & A \\
\hline
\end{tabular}

Değerlendirme: Olumsuz=Eksi (E), Kabul Edilebilir= Nötr (N); Olumlu=Artı (A), Öğeye rastlanmadı=Yok $(Y)$ 


\section{Ek-5. Okul Öncesinde Özel Gereksinimli Bireylere Yönelik Farkındalık Geliştirmek için Önerilen Çocuk Kitapları}

\begin{tabular}{|c|c|}
\hline Kitap Adt & Ōzet \\
\hline 1. Greg'in Zaferieri* & 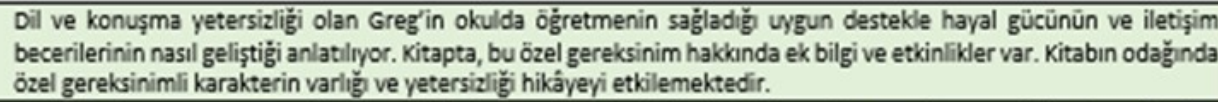 \\
\hline $\begin{array}{l}\text { 2. Șuşu, Can ve } \\
\text { Dörtteker* }\end{array}$ & $\begin{array}{l}\text { Bisikleti olan Șuşu ve ortopedik yetersizliği olan Can'ın tekerlekli aletleri ile parkta gezerken yaşadiklan kaza üzerine } \\
\text { başlayan arkadaşlıklan anlatilıor. Kitabın odağında varlığı ile hikâyeyi etkilemeyen veya en az düzeyde etkileyen bir } \\
\text { özel gereksinimli karakter vardır. }\end{array}$ \\
\hline $\begin{array}{l}\text { 3. Büyükbabam } \\
\text { Değişti* }\end{array}$ & 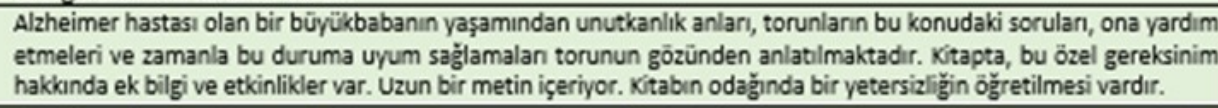 \\
\hline 4. Dedemin Müziği* & $\begin{array}{l}\text { Alzheimer hastası olan ancak piyano çalmayı unutmayan bir dedenin torunlan ile aynı evde yaşaması ve ardından } \\
\text { bakım evine yerleștirilmesi torunun gózǔnden anlatilmaktadır. Uzun bir metin içeriyor. Kitabın odağında özel } \\
\text { gereksinimli karakterin varlığ ve yetersizliği hikáyeyi etkilemektedir. }\end{array}$ \\
\hline $\begin{array}{l}\text { 5. Bende Astım } \\
\text { Var* }\end{array}$ & $\begin{array}{l}\text { Futbol oynarken rahatsılanan bir çocuk astım hastası olduğunu öğrendikten sonra yaşadığı endişeleri ve yalnız } \\
\text { olmadığııı anlayınca korkularını yendiğjini anlatıyor. Özel gereksinimli bireyin bakış açısını yansıtması olumlu ancak } \\
\text { uzun bir metin içeriyor. Kitapta, bu özel gereksinim hakkında ek bilgi ve etkinlikler var. Kitabın odağında bir } \\
\text { yetersizlig̈in öğretilmesi vardır. }\end{array}$ \\
\hline $\begin{array}{l}\text { 6. Duyamamok } \\
\text { Böyle Bir şey* }\end{array}$ & 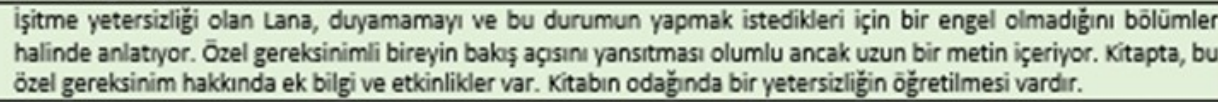 \\
\hline $\begin{array}{l}\text { 1. Cemile } \\
\text { Arkadassıno } \\
\text { Yordim Ediyor }\end{array}$ & $\begin{array}{l}\text { Cemile'nin ortopedik yetersizliğj olan Asım ile tanıșması ve beraber oynarlarken onun aslında ne kadar hızlı hareket } \\
\text { ettigini fark etmesi anlatilyor. Kitabın odağında özel gereksinimli karakterin varıı̆ı ve yetersizliğji hikâyeyi } \\
\text { etkilemektedir. }\end{array}$ \\
\hline 2. Forklı oma Aynı & 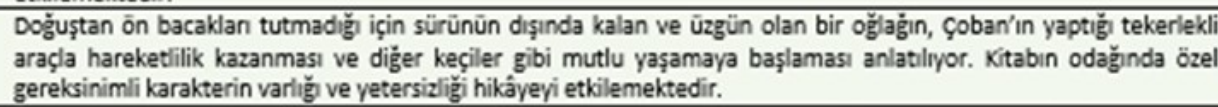 \\
\hline $\begin{array}{l}\text { 3. Gülümsemek } \\
\text { iyidir }\end{array}$ & $\begin{array}{l}\text { Mimi'nin işitme yetersizliği olan komşu çocuğu ile tanışması ve gülümseme dili ile anlaşmaları anlatlıyor. Kitabın } \\
\text { odağında ôzel gereksinimli karakterin varığı ve yetersizliği hikâyeyi etkilemektedir. }\end{array}$ \\
\hline $\begin{array}{l}\text { 4. Sora'ya Findik } \\
\text { Yok }\end{array}$ & $\begin{array}{l}\text { Sara, gıda alerjisi olduğunu ögrendikten sonra yaģadıklarını ve bu duruma nasıll uyum sağladığını anlatıyor. Ōzel } \\
\text { gereksinimli bireyin bakış açıını yansitması olumlu ancak cadı, büyücū gibi yaşa uygun olmayan sözcükler ve didaktik } \\
\text { bir metin içermektedir. Kitapta, bu ōzel gereksinim hakkında ek bilgi ve etkinlikler var. Kitabın odağında bir } \\
\text { yetersizliğin öğretilmesi vardır. }\end{array}$ \\
\hline 5. Aleks çok Hossas & 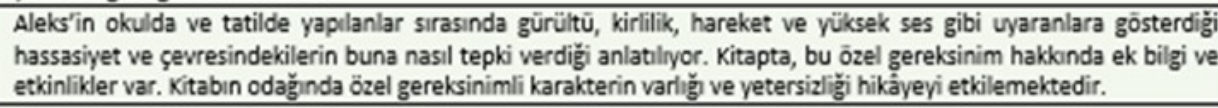 \\
\hline 6. Yavoşla Pisican & $\begin{array}{l}\text { Sürekli hareket halinde olan Pisican adlı kedinin oyun ve merak dolu bir gününden kesitler sunularak derin nefes } \\
\text { alarak dinlenmesi ve sakinleşmesi anlatllyor. Kitabın odağında özel gereksinimli karakterin varlığı ve yetersizlï̆i } \\
\text { hikâyevi etkilemektedir. }\end{array}$ \\
\hline 1. Seslerin Perisi Işıı & 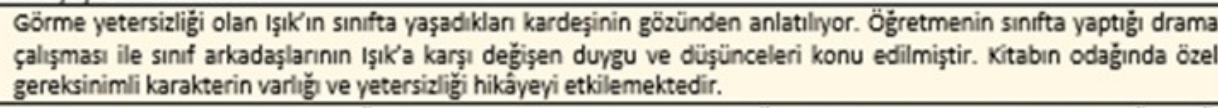 \\
\hline $\begin{array}{l}\text { 2. Anyes'in } \\
\text { Sokorllklorn }\end{array}$ & 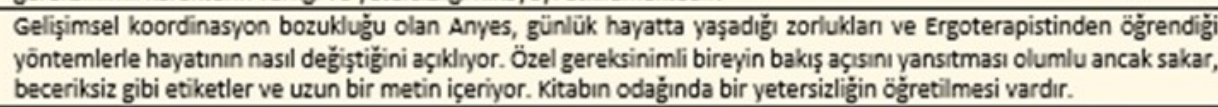 \\
\hline 3. Borı̧̧'in Gezintisi & 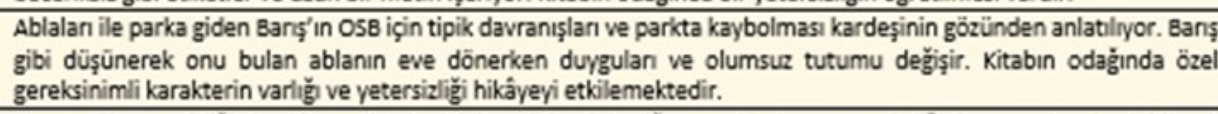 \\
\hline 4. Yopobilirim & 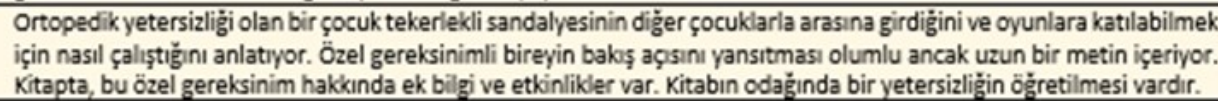 \\
\hline
\end{tabular}

